\title{
Pharmacological Properties and Biological Functions of the GPR17 Receptor, a Potential Target for Neuro-Regenerative Medicine
}

\author{
Marta Fumagalli, Davide Lecca, Giusy T. Coppolino, \\ Chiara Parravicini, and Maria P. Abbracchio
}

\begin{abstract}
In 2006, cells heterologously expressing the "orphan" receptor GPR17 were shown to acquire responses to both uracil nucleotides and cysteinylleukotrienes, two families of signaling molecules accumulating in brain or heart as a result of hypoxic/traumatic injuries. In subsequent years, evidence of GPR17 key role in oligodendrogenesis and myelination has highlighted it as a "model receptor" for new therapies in demyelinating and neurodegenerative diseases. The apparently contrasting evidence in the literature about the role of GPR17 in promoting or inhibiting myelination can be due to its transient expression in the intermediate stages of differentiation, exerting a pro-differentiating function in early oligodendrocyte precursor cells (OPCs), and an inhibitory role in late stage maturing cells. Meanwhile, several papers extended the initial data on GPR17 pharmacology, highlighting a "promiscuous" behavior of this receptor; indeed, GPR17 is able to respond to other emergency signals like oxysterols or the pro-inflammatory cytokine SDF-1, underlying GPR17 ability to adapt its responses to changes of the surrounding extracellular milieu, including damage conditions. Here, we analyze the available literature on GPR17, in an attempt to summarize its emerging biological roles and pharmacological properties.
\end{abstract}

Marta Fumagalli and Davide Lecca contributed equally to this work.

M. Fumagalli, D. Lecca, G.T. Coppolino, C. Parravicini, and M.P. Abbracchio $(\bowtie)$

Laboratory of Molecular and Cellular Pharmacology of Purinergic Transmission, Department of Pharmacological and Biomolecular Sciences, Università degli Studi di Milano, Via Balzaretti 9, 20133 Milan, Italy

e-mail: mariapia.abbracchio@unimi.it 


\section{Keywords}

Differentiation - GPCR - Multiple sclerosis - Myelination • Oligodendrocyte precursor cells

\section{Abbreviations}

$\begin{array}{ll}\text { CNS } & \begin{array}{l}\text { central nervous system } \\ \text { cysLT }\end{array} \\ \text { EAE } & \begin{array}{l}\text { experinyl-leukotrienes } \\ \text { encephalomyelitis } \\ \text { extracellular signal-regulated } \\ \text { kinases 1 and } 2 \\ \text { frontal affinity chromatography- }\end{array} \\ \text { FACS- } & \begin{array}{l}\text { mass spectrometry } \\ \text { MS }\end{array} \\ \text { GPCRs } & \begin{array}{l}\text { G-protein coupled receptors } \\ \text { homology modeling } \\ \text { HM }\end{array} \\ \text { Lys } & \begin{array}{l}\text { lysolecithin } \\ \text { middle cerebral artery occlusion }\end{array} \\ \text { MCAo } & \text { multiple sclerosis } \\ \text { MS } & \text { Nomenclature Committee of the } \\ \text { NC- } & \begin{array}{l}\text { International } \\ \text { IUPHAR }\end{array} \\ \text { OLs } & \begin{array}{l}\text { Pharmacology } \\ \text { oligodendrocytes } \\ \text { oligodendrocyte precursor cells } \\ \text { OPCs }\end{array} \\ \text { MBP } & \text { myelin basic protein }\end{array}$

\section{Introduction: The History of GPR17}

In 2006, a paper was published where it was demonstrated that cells heterologously expressing the "orphan" receptor GPR17 (i.e., a molecularly identified, 339 amino acid-long $\mathrm{G}_{\mathrm{i}}$-protein-coupled receptor that still lacked a defined ligand) acquired responses to both uracil nucleotides (such as UDP, UDP-glucose, UDP-galactose) and cysteinyl-leukotrienes (cysLTs, like $\mathrm{LTC}_{4}$ and $\mathrm{LTD}_{4}$ ) (Ciana et al. 2006), two chemically unrelated families of signaling molecules that are known to massively accumulate in organs like the brain or the heart as a result of hypoxic/traumatic injuries. Uracil nucleotides and cysLTs were already known to exert multiple biological effects via the activation of separate G-protein-coupled 77 receptors (GPCRs): the eight recognized P2Y 78 receptor subtypes (the $\mathrm{P} 2 \mathrm{Y}_{1,2,4,6,11,12,13,14} 79$ receptors, (Abbracchio et al. 2006) and the two 80 CysLT1 and CysLT2 receptors. Interestingly, the 81 GPR17 sequence had been originally described 82 as the result of a cloning strategy based on the 83 use of RT-PCR degenerate oligonucleotide 84 primers designed on the sequences of the $\mathrm{P}_{2} \mathrm{Y}_{1} 85$ and $\mathrm{P}_{2} \mathrm{Y}_{2}$ receptors, with the final aim of 86 identifying new members of this receptor family 87 (Blasius et al. 1998). GPR17 was later found to 88 be at an intermediate structural and phylogenetic 89 position between already known P2Y and CysLT 90 receptors, and GPR99, recently proposed as the 91 third CysLT receptor (also known as 92 2-oxoglutarate receptor 1, OXGR1) (Kanaoka 93 et al. 2013) (Fig. 1), in the so called "purine 94 receptor cluster" of class A GPCRs (Fredriksson 95 et al. 2003). GPR17 also emerged as represented 96 the closest receptor to a common ancestor that, 97 during evolution, could have generated both P2Y 98 and CysLT receptors (Ciana et al. 2006; 99 Parravicini et al. 2008; Parravicini et al. 2010). 100 To further highlight GPR17 structural similarity 101 to the other members of the P2Y family, a partial 102 sequence of the rat receptor was initially 103 identified from rat striatum by employing oligo- 104 nucleotide primers specifically designed on the 105 sequence of human $\mathrm{P}^{2} \mathrm{Y}_{11}$ (Lecca and 106 Abbracchio 2008). Of note, a human GPR17 107 long splice variant encoding a receptor with a 108 28-amino acid longer NH2 terminal (for a total 109 of 367 amino acids instead of 339) had been also 110 identified in very early studies aimed at discov- 111 ering new members of the chemokine receptor 112 family (in this respect, see also Sect. 2.1) 113 (Blasius et al. 1998). Genomic analysis revealed 114 a three-exon structure of the hGPR17 gene, with 115 two putative open reading frames. While the 116 "short isoform" derives from splicing of the 117 


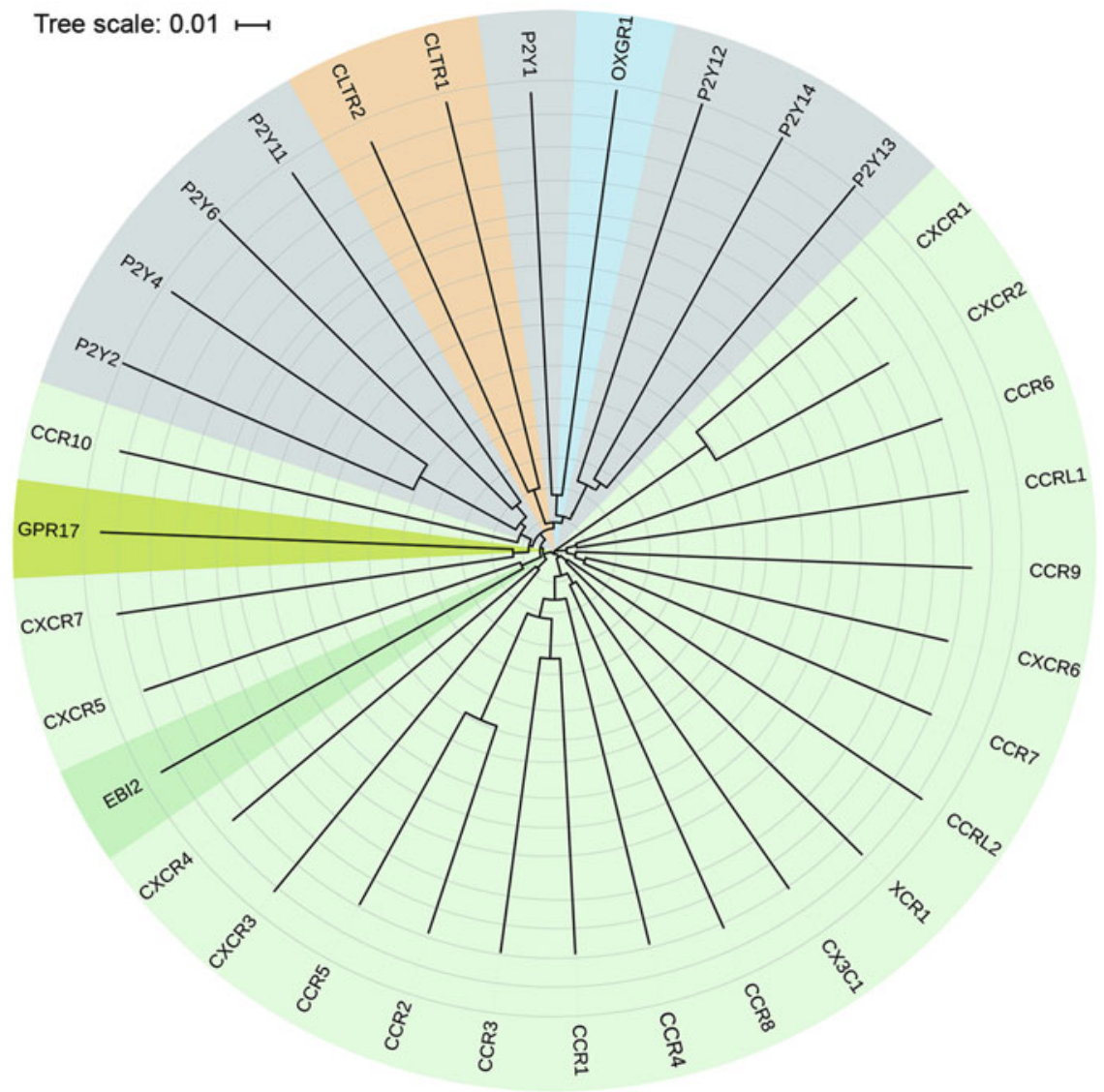

Fig. 1 Phylogenetic tree illustrating the relationship of GPR17 to selected structurally related class-A GPCRs. The evolutionary relationship analysis is based on a multiple sequence alignment performed on homologous GPCR sequences using TM-Coffee, a module of the T-Coffee package optimized for transmembrane proteins (Chang et al. 2012). Receptors belonging to the same

second exon, the "long one" contains all three exons of the hGPR17 gene, leading to a transcript which is 1104 bp in length (Blasius et al. 1998; Pugliese et al. 2009). Interestingly, quantitative gene expression studies revealed that GPR17 short isoform is expressed more abundantly in the brain than the long one (a tenfold increase), whereas the opposite was observed in heart and kidney. Pharmacological profile of the long isoform also showed that some differences exist between the two GPR17 receptor isoforms (Pugliese et al. 2009; Benned-Jensen and Rosenkilde 2010). family are clustered according to the following color code: grey for purinergic receptors $(\mathrm{P} 2 \mathrm{Y})$, orange for cysteinyl-leukotriene receptors (CysLT), light green for chemokine receptors (CXCRn, CCRn, XCRn), emerald green for Epstein-Barr virus-induced G-protein coupled receptor 2 (EBI2), sky blue for 2-Oxoglutarate receptor 1 (OXGR1/GPR99), apple green for GPR17

In 2006, there were already papers reporting 131 functional interactions between "classical" P2Y 132 and CysLT receptors. For example, under some 133 conditions, the CysLT1 receptor antagonist 134 montelukast effectively antagonized the 135 responses evoked by purinergic P2Y receptors 136 (Capra et al. 2005; Mamedova et al. 2005). Con- 137 versely, the $\mathrm{P}_{2} \mathrm{Y}_{12}$ receptor had been reported to 138 be also activated by $\mathrm{LTE}_{4}$ (Paruchuri et al. 2009), 139 suggesting the existence of some kind of ligand/ 140 receptor promiscuity between the P2Y and 141 CysLT receptor families. On this basis, the iden- 142 tification of GPR17 as the first dual member of 143 the "purine receptor cluster" able to respond to 144 
both purinergic and cysLT ligands (Ciana et al. 2006) represented the demonstration of a further level of interaction between these two chemically unrelated, but functionally interconnected, systems. Later studies extended the response profile of this receptor to other classes of endogenous "emergency" molecules connected to oxidative stress, neuroinflammation and neurodegeneration, i.e., oxysterols and chemokine stromal derived factor-1 (SDF-1) (Parravicini et al. 2016), further highlighting the promiscuous behaviour of GPR17. Of note, a phylogenetic analysis among structurally related class-A GPCRs (Parravicini et al. 2008, 2010, 2016; Sensi et al. 2014), suggest that, besides P2Y and CysLT receptors, GPR17 holds a tight evolutionary relationship also with chemokine receptors and Epstein-Barr virus-induced G-protein coupled receptor 2 (EBI2) (Fig. 1). The possibility that GPR17 can be activated by diverse family of ligands underlines the relevance of a new transversal signaling mechanism that synchronizes all these emergency molecules and their receptors under specific neurodegenerative conditions. Such a high promiscuity in receptor behaviour is often found in receptors involved in immunological responses and may, at least in part, depend on GPR17 ability to form dimers with other related receptors, thus widening the array of pharmacological responses (see also Sect. 2.2.1).

In subsequent years, new data have revealed a key role for GPR17 in oligodendrogenesis and myelination (Lecca et al. 2008; Chen et al. 2009). However, while some authors have provided evidence for a stimulatory role of GPR 17 in the specification and maturation of oligodendrocyte precursor cells (OPCs), some others have proposed an inhibitory role. Here, we aim at analyzing all the available literature on GPR17 in an attempt to provide an overview of the different biological and pharmacological data emerged from all these papers.

\section{GPR17 Characterization}

\subsection{Receptor Structure, Amino Acid 189 Homology with Phylogenetically 190 Related GPCRs and Binding Sites 191}

GPR17 displays the typical 7-transmembrane 192 (TM) domain topology of GPCRs, with an 193 amino acid identity with the known P2Y and 194 CysLT receptors between 21 and 48\% 195 (Abbracchio et al. 2006; Lecca and Abbracchio 196 2008). All these receptors show partial or com- 197 plete conservation of a $\mathrm{H}-\mathrm{X}-\mathrm{X}-\mathrm{R} / \mathrm{K}$ amino acid 198 motif in TM6 (and also of a K-E-X-X-L motif in 199 TM7, in the case of $\mathrm{P}_{2} \mathrm{Y}_{12}, \mathrm{P}_{2} \mathrm{Y}_{13}, \mathrm{P}_{2} \mathrm{Y}_{14}$ ) that 200 are important for ligand recognition and have 201 been proposed to represent specific molecular 202 signatures for these receptors (Lecca and 203 Abbracchio 2008) (see also below). Homology 204 Modelling (HM) studies combined with other in 205 silico tools have been performed to raise hypoth- 206 esis on the molecular interaction between GPR17 207 and its putative endogenous ligands (Parravicini 208 et al. 2008, 2010; Calleri et al. 2010), as well as 209 to identify new potential ligands (Eberini et al. 210 2011) (see also Sect. 2.2.2). In these studies, in 211 silico receptor modeling was performed using 212 different templates, according to the progressive 213 availability of new high-resolution GPCR 214 structures. Starting from bovine rhodopsin, that, 215 since 2000, has represented for many years the 216 only atomistic scaffold for the structural investi- 217 gation of GPCRs, the recent explosion in the 218 resolution of GPCR crystal structures has given 219 access to detailed structural information previ- 220 ously unavailable, allowing the construction of 221 more and more accurate GPR17 models (Fig. 2). 222

For example, in 2010, crystallization of 223 human CXCR4 (Wu et al. 2010) provided a sig- 224 nificant improvement in the accuracy of GPR17 225 modelling because this structure enabled to reli- 226 ably describe the extracellular regions of the 227 receptor, especially extracellular loop 2 (ECL2) 228 and the disulphide bridge linking the N-terminal 229 to ECL3, known to be crucial in ligand molecular 230 recognition (Wheatley et al. 2012), but for which 231 none of the earlier templates was suitable. More 232 


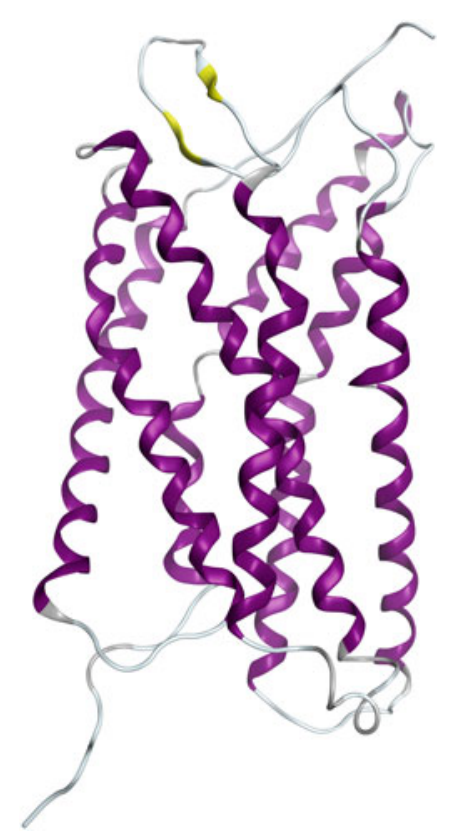

Fig. 2 Three-dimensional homology model of the human GPR17. Topological domains are represented as ribbon and coloured according to their secondary structure: magenta for alpha-helices; yellow for beta-sheets; white for loops and grey for turns recently, modelling of GPR17 has been further improved thanks to the atomic resolution of the structures of two members of the P2Y receptor family: the human $P 2 Y_{12}$ (Zhang et al. 2014) and $\mathrm{P} \mathrm{Y}_{1}$ (Zhang et al. 2015).

Globally, all the in silico results on the short isoform of GPR17 suggest that its nucleotide binding pocket is similar to that described for the other P2Y receptors (including the TM6 HXXR/K motif designated to accommodate the phosphate moieties of nucleotide ligands (Parravicini et al. 2008; Jiang et al. 1997), and that this site is also shared by other small molecules identified as GPR 17 ligands, including oxysterols and new synthetic compounds (Sensi et al. 2014; Eberini et al. 2011). According to these studies, also the nucleotide-derivative antagonist cangrelor binds to the same binding pocket, behaving as a competitive antagonist for orthosteric ligands.

In both P2Y and CysLT1 and CysLT2 receptors, ligand binding is critically dependent on the basic Arginine residue belonging to the conserved TM6 motif (Parravicini et al. 2010; 256 Temporini et al. 2009). Computational studies 257 suggested that this also holds true for Arg255 of 258 GPR17 (Parravicini et al. 2008). To assess the 259 actual role of this residue in receptor binding, this 260 basic amino acid was mutated to isoleucine, and 261 an in silico mutant GPR17 receptor (R255I) was 262 generated. Using steered molecular dynamics 263 simulations (SMD), forced unbinding of the 264 endogenous ligand UDP from both wild type 265 (WT) and R255I receptor models of GPR17 266 was modeled in silico. The energy required to 267 unbind UDP from the nucleotide binding pocket 268 of GPR17 was higher for the WT than for the 269 mutated R255I receptor, and the exit of the 270 ligand from its intracellular cavities occurred 271 earlier in the R255I model compared to the WT 272 receptor. Generation and expression of the 273 mutated receptor in $1321 \mathrm{~N} 1$ cells confirmed 274 also in vitro that the mutation was not silent 275 (Calleri et al. 2010).

Besides the orthosteric binding site, in silico 277 studies suggested that GPR17 also possesses an 278 "accessory" binding site in a region formed by 279 extracellular loops ECL2, ECL3 and the N- ter- 280 minal, which also faces the extracellular space. 281 This external accessory binding site could guide 282 small agonist ligands to the deeper principal 283 binding site in a multistep mechanism of activa- 284 tion. Thanks to further in silico investigations, 285 that showed the possibility of GPR 17 to be 286 stimulated also by a large peptide ligand such 287 as SDF-1, the extracellular recognition site has 288 been extensively characterized and GPR 17 rec- 289 ognition mechanism has been compared to those 290 of some peptide receptors (Parravicini et al. 291 2016), in which a two-step model of receptor 292 activation, passing through both an extracellular 293 and a TM binding site, has been proposed 294 (Rajagopalan and Rajarathnam 2004).

Due to the intrinsic inaccuracy of the standard 296 template-based HM techniques in predicting 297 conformations of highly flexible and unaligned 298 loop sequences in absence of adequate templates, 299 no modeling studies are yet available for the long 300 isoform of GPR17. Nevertheless, we can specu- 301 late that the N-terminal may influence the bind- 302 ing affinity of nucleotide agonists via a different 303 
304 conformation of the external accessory binding 305 site, resulting in a slightly different pharmaco306 logical profile of the long isoform with respect to 307 the short one (Pugliese et al. 2009).

\subsection{Pharmacology and Signaling Pathways}

\subsubsection{Putative Endogenous Ligands and Transduction Systems}

314 In the initial studies, only GPR17 short isoform 315 has been characterized, and both the human, rat

(Ciana et al. 2006) and the previously unidentified mouse GPR17 receptors (Lecca and Ceruti 2008) were shown to respond to UDP, UDP-glucose, UDP-galactose and $\mathrm{LTC}_{4}$ and $\mathrm{LTD}_{4}$, with comparable profiles that were highly conserved across species (the chemical structures of UDP-glucose and $\mathrm{LTD}_{4}$ are reported in Fig. 3). Interestingly, the concentration ranges at which uracil nucleotides and cysLTs activated GPR17 (i.e., $\mu \mathrm{M}$ and $\mathrm{nM}$ ranges, respectively) were fully consistent with those necessary for these endogenous ligands to activate their already known cognate P2Y and CysLT receptors (Abbracchio et al. 2006; Brink et al. 2003). Very similar agonist responses were detected in a number of different cell lines (1321N1, CHO, COS-7, HEK-293 cells). The $1321 \mathrm{~N} 1$ cells was the most appropriate cells to test GPR17 responses, since they are one of the few cell lines that do not endogenously express any functional purinergic or CysLT receptors. Responses were highly specific, since no response was ever found in cells transfected with the empty vector. The antagonist response profile of GPR17 was also rather peculiar. Activation by uracil nucleotides was reversed by some typical purinergic antagonists like the $\mathrm{P}_{2} \mathrm{Y}_{1}$ antagonist MRS2179 or the $\mathrm{P}_{2} \mathrm{Y}_{12}$ antagonist cangrelor (Fig. 3). Conversely, responses to cysLTs were inhibited by typical CysLT receptor antagonists like the already marketed drug montelukast (Fig. 3) and pranlukast (Ciana et al. 2006).

GPR17 responses were demonstrated by using $\left[{ }^{35} \mathrm{~S}\right] \mathrm{GTP} \gamma \mathrm{S}$ binding, a typical functional assay for agonists acting at $\mathrm{G}_{\mathrm{i}}$ coupled receptors 351 (Kotani et al. 2001; Marteau et al. 2003; 352 Fumagalli et al. 2004). Under some 353 circumstances, activation of GPR 17 could also 354 increase intracellular calcium levels via a phos- 355 pholipase C mediated pathway; however, this 356 effect occurred only in about $30 \%$ of $1321 \mathrm{~N} 1357$ transfected cells, suggesting preferential cou- 358 pling to the adenylyl cyclase pathway (Ciana 359 et al. 2006). In subsequent studies, GPR 17 pecu- 360 liar profile was confirmed in many other distinct 361 assays independently performed in different 362 laboratories. Concentration-dependent inhibition 363 of forskolin-stimulated adenylyl cyclase was also 364 shown in oligodendendrocyte precursor cells 365 (OPCs), the cell type natively expressing 366 GPR17 at highest levels (Fumagalli et al. 367 2011a) (Table 1). Inhibition of cAMP was fully 368 counteracted by the same antagonists utilized in 369 the $\left[{ }^{35} \mathrm{~S}\right] \mathrm{GTP} \gamma \mathrm{S}$ binding. In 2009, another paper 370 appeared where, in GPR17 expressing 1321N1 371 cells, enhancement of an outward rectifying $\mathrm{K}^{+} 372$ current was shown upon addition of either uracil 373 nucleotides or cysLTs (Pugliese et al. 2009). 374 These effects were blocked by MRS2179, 375 cangrelor and montelukast. A few years later, 376 these same authors showed that similar delayed 377 rectifier $\mathrm{K}^{+}$currents were stimulated in a concen- 378 tration dependent manner by GPR17 ligands in a 379 subpopulation of OPCs and 380 pre-oligodendrocytes, but not in terminally 381 mature cells, fully in line with the transient 382 expression of GPR 17 during OPC specification 383 (in this respect, see also Sect. 3.1.1) (Coppi et al. 384 2013). This effect was blocked by MRS2179 and 385 cangrelor and sensitive to the $\mathrm{K}^{+}$channel blocker 386 tetraethyl-ammonium. Importantly, the latter 387 also inhibited oligodendrocyte maturation, to 388 support previous literature data on the impor- 389 tance of these currents in OPC differentiation. $\quad 390$

Fewer studies are available on hGPR17 long 391 isoform. In the electrophysiological study 392 already mentioned above, no significant 393 differences between the short and long isoforms 394 were detected (Pugliese et al. 2009). In 2010, 395 Benned-Jensen and Rosenkilde independently 396 confirmed the ability of heterologously 397 expressed GPR17 to respond to uracil 398 


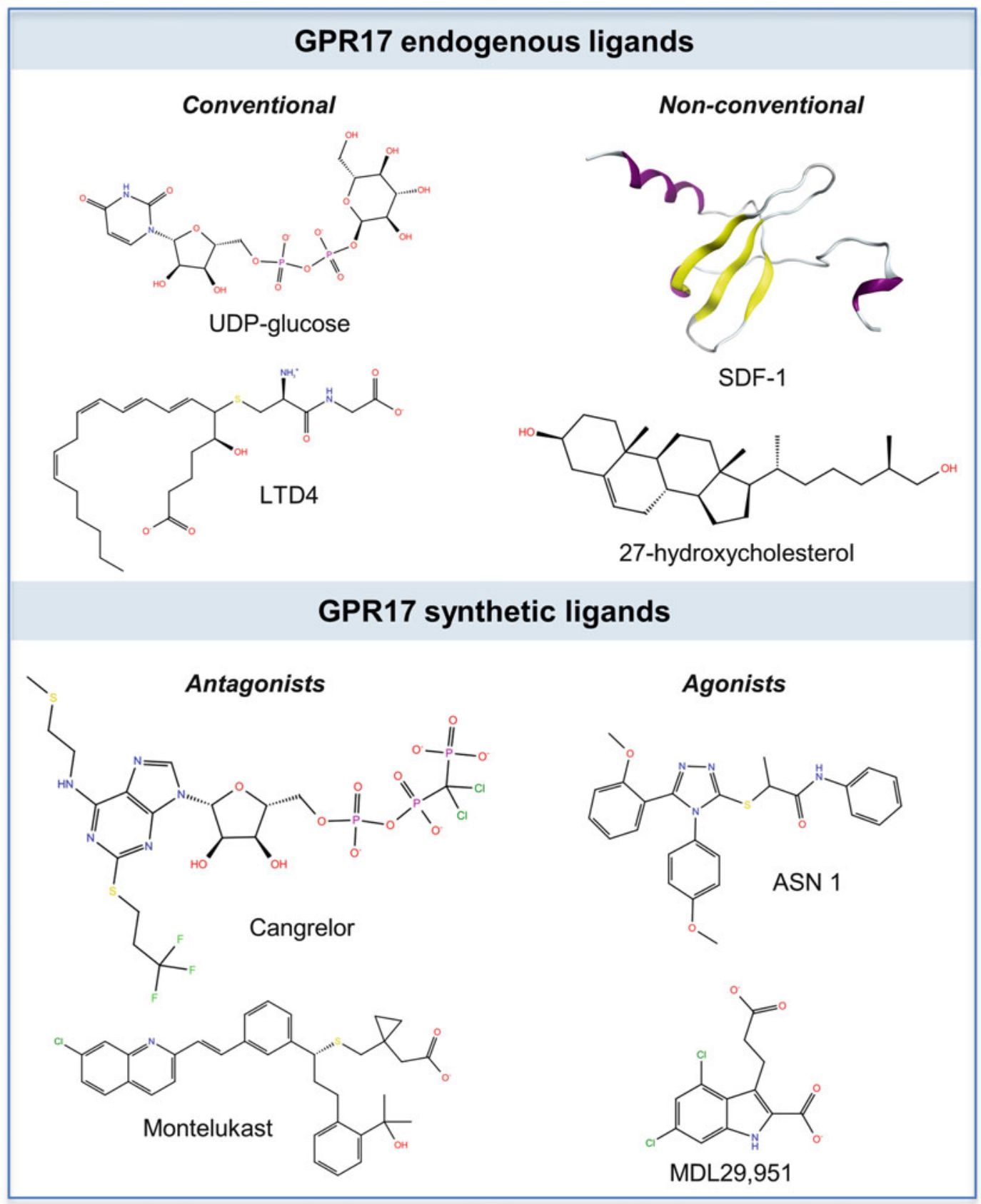

Fig. 3 Chemical structures of endogenous and synthetic compounds reported to bind GPR17. CAS Registry number of synthetic ligands are the following:

399 nucleotides in a cAMP response element binding 400 (CREB) trans-reporter luciferase assay in 401 HEK293 cells (Benned-Jensen and Rosenkilde 402 2010). Both UDP, UDP-glucose and
MDL29,951 \#130798-51-5; ASN-1: \#483283-39-2. For SDF-1, a representative X-ray structure deposited in the Protein Data Bank is reported (Pdb code: 1QG7)

UDP-galactose activated GPR17 short isoform 403 with $\mathrm{EC}_{50}$ values exactly in the same $\mu \mathrm{M}$ range 404 that had been previously reported in both the [ [ ${ }^{35} 405$ S]GTP $\gamma$ S binding (Ciana et al. 2006; Lecca et al. 406 
Table 1 GPR17 signaling in native systems and relevant pharmacology

\begin{tabular}{|c|c|c|c|c|}
\hline $\begin{array}{l}\text { Tested } \\
\text { ligand }\end{array}$ & Type of cells & Signaling & $\mathrm{EC}_{50} / \mathrm{IC}_{50}$ values & Reference \\
\hline \multirow[t]{6}{*}{$\begin{array}{l}\text { UDP- } \\
\text { glucose }\end{array}$} & $\begin{array}{l}\text { Rat primary } \\
\text { OPCs }\end{array}$ & Inhibition of cAMP production & $\begin{array}{l}\mathrm{IC}_{50}: \\
424.7 \pm 125 \mathrm{nM}\end{array}$ & $\begin{array}{l}\text { Fumagalli et al. } \\
\text { (2011a) }\end{array}$ \\
\hline & $\begin{array}{l}\text { Rat primary } \\
\text { OPCs }\end{array}$ & Outward $\mathrm{K}^{+}$currents & $\mathrm{EC}_{50}: 4.6 \mu \mathrm{M}$ & Coppi et al. (2013) \\
\hline & $\begin{array}{l}\text { Rat primary } \\
\text { OPCs }\end{array}$ & Association to GRK5 & N.A. & Daniele et al. (2014) \\
\hline & $\begin{array}{l}\text { Rat primary } \\
\text { OPCs }\end{array}$ & $\begin{array}{l}\beta \text {-arrestin dependent ERK1/ } \\
2 \text { activation }\end{array}$ & N.A. & Daniele et al. (2014) \\
\hline & Oli-neu cells & Clathrin-mediated endocytosis & N.A. & $\begin{array}{l}\text { Fratangeli et al. } \\
(2013)\end{array}$ \\
\hline & PC12 cells & ERK1/2 and p38 phosphorylation & N.A. & Daniele et al. (2010) \\
\hline \multirow[t]{6}{*}{$\begin{array}{l}\mathrm{UDP} \\
\mathrm{LTD}_{4}\end{array}$} & $\begin{array}{l}\text { Rat primary } \\
\text { OPCs }\end{array}$ & Inhibition of cAMP production & $\begin{array}{l}\mathrm{IC}_{50}: \\
1.29 \pm 0.07 \mu \mathrm{M}\end{array}$ & $\begin{array}{l}\text { (Fumagalli et al. } \\
\text { 2011a) }\end{array}$ \\
\hline & $\begin{array}{l}\text { Rat primary } \\
\text { OPCs }\end{array}$ & Inhibition of cAMP production & $\begin{array}{l}\mathrm{IC}_{50}: \\
2.85 \pm 0.89 \mathrm{nM}\end{array}$ & $\begin{array}{l}\text { Fumagalli et al. } \\
\text { (2011a) }\end{array}$ \\
\hline & $\begin{array}{l}\text { Rat primary } \\
\text { OPCs }\end{array}$ & Association to GRK2 & N.A. & Daniele et al. (2014) \\
\hline & $\begin{array}{l}\text { Rat primary } \\
\text { OPCs }\end{array}$ & CREB activation & N.A. & Daniele et al. (2014) \\
\hline & PC12 cells & ERK1/2 and p38 phosphorylation & N.A. & Daniele et al. (2010) \\
\hline & Oli-neu cells & Clathrin-mediated endocytosis & N.A. & $\begin{array}{l}\text { Fratangeli et al. } \\
(2013)\end{array}$ \\
\hline $\mathrm{LTE}_{4}$ & $\begin{array}{l}\text { Rat primary } \\
\text { OPCs }\end{array}$ & Inhibition of cAMP production & $\mathrm{IC}_{50}: 51.8 \pm 6.6 \mathrm{pM}$ & $\begin{array}{l}\text { Fumagalli et al. } \\
\text { (2011a) }\end{array}$ \\
\hline \multirow[t]{2}{*}{ MDL29,951 } & $\begin{array}{l}\text { Rat primary } \\
\text { OPCs }\end{array}$ & Inhibition of cAMP production & N.A. & Hennen et al. (2013) \\
\hline & $\begin{array}{l}\text { Rat primary } \\
\text { OPCs }\end{array}$ & $\mathrm{Ca}^{2+}{ }_{\mathrm{i}}$ increase & N.A. & Hennen et al. (2013) \\
\hline
\end{tabular}

N.A.: Not available

2008) and in frontal affinity chromatographymass spectrometry (FAC-MS) studies (Calleri et al. 2010; Temporini et al. 2009). Much lower potencies to uracil nucleotides were observed for the long receptor isoform, with a 50-170 fold increase in $\mathrm{EC}_{50}$ (Benned-Jensen and Rosenkilde 2010). Moreover, no responses to cysLTs were detected either on the short or long isoform, nor were cysLTs able to induce GPR17 removal from the membrane and internalization. This is in contrast with subsequent studies on cells natively expressing the receptor (Fratangeli et al. 2013) (see below). This may depend on differences in the conformation/ability of the recombinant receptor to respond to agonists compared to the native one, as well as on the fact that, in heterologously expressing systems, constitutive activity of transfected receptors may significantly alter ligand behavior (Kenakin 425 2001; Im 2013) (see also Conclusions). In this 426 respect, Benned-Jensen and Rosenkilde indeed 427 reported a notable constitutive activation of 428 recombinant GPR17 resulting in potent inhibi- 429 tion of forskolin stimulated adenylyl cyclase in 430 the absence of any endogenous ligand (Benned- 431 Jensen and Rosenkilde 2010). 432

At the same time, another paper suggested 433 GPR17 as a negative regulator of the CysLT1 434 receptor (Maekawa et al. 2009). This effect was 435 proposed to depend on the formation of a 436 CysLT1-GPR17 heteromer, as suggested by 437 co-immunoprecipitation studies in $\mathrm{CHO}$ cells. 438 The interaction between GPR17 and CysLT1 439 was further confirmed in primary human mono- 440 cyte cells and in a rodent knock out GPR17 441 model, thus extending to GPR17 the previously 442 
reported interaction and promiscuity between different members of the "purine receptor cluster". These data indicate that, besides working on its own, GPR17 may also modify the function of other related receptors by the formation of heteromers.

In 2010, the first paper describing the characteristics of GPR17 in a native system (rat pheocromocytoma PC12 cells) was published (Daniele et al. 2010) (Table 1). GPR17 was not expressed in undifferentiated PC12 cells but was specifically induced by a 10-day NGF treatment, suggesting a role in the control of neuronal differentiation. Both UDP-glucose and $\mathrm{LTD}_{4}$ induced a significant pro-survival effect on PC12 cells. By in vitro silencing experiments with small interfering RNAs and by using receptor antagonists, these effects were confirmed to be mediated by the selective activation of GPR17. In differentiated PC12 cells, UDP-glucose and $\mathrm{LTD}_{4}$ caused a significant increase in extracellular signal-regulated kinases 1 and 2 (ERK1/2) phosphorylation. ERK activation induced by the two agonists occurred with different kinetics: $\mathrm{LTD}_{4}$ induced a transient ERK activation that returned to basal value within 120 min. In contrast, ERK phosphorylation induced by UDP-glucose was maintained over basal values for $120 \mathrm{~min}$ and the activation kinetics appeared to be biphasic with two peaks, one at 15 and the other one at $120 \mathrm{~min}$. In addition, incubation of cells with the purinergic antagonist cangrelor completely counteracted UDP-glucose effects at all tested incubation times (Daniele et al. 2010). These data confirmed the responses to uracil nucleotides and cysLTs already seen on the recombinant receptors, and suggested, for the first time, that endogenous GPR17 ligands can couple to distinct $G$ proteins and intracellular pathways, a finding that was later confirmed by other studies (Hennen et al. 2013; Daniele et al. 2014). The signaling pathways of native GPR 17 are summarized in Table 1.

In 2011, in another study that independently confirmed the purinergic component of GPR17, Buccioni and coworkers (Buccioni et al. 2011) exploited an innovative and non-radioactive functional cAMP assay to monitor GPR17 acti- 490 vation (and the effects of various ligands) 491 through changes in intracellular cAMP 492 concentrations by using a mutant form of 493 Photinus pyralis luciferase into which a cAMP- 494 binding protein moiety had been inserted 495 (GloSensor cAMP reagent). In HEK293 cells 496 stably transfected with the GloSensor reagent, 497 transient expression of hGPR17 resulted in the 498 appearance of highly specific concentration- 499 dependent responses to both UDP, 500 UDP-glucose and UDP-galactose and to a series 501 of UDP and ATP derivatives that behaved as 502 either agonist or antagonists, with $\mathrm{EC}_{50}$ values 503 that were very similar to those obtained in paral- 504 lel on $\left[{ }^{35} \mathrm{~S}\right] \mathrm{GTP} \gamma \mathrm{S}$ binding. In this system, 505 cysLTs were not tested, due to the high constitu- 506 tive expression of traditional CysLT receptors in 507 the HEK293 cells (Ciana et al. 2006; Buccioni 508 et al. 2011).

\subsubsection{GPR17 Non-conventional Ligands 518}

In the last years, the increasing number of class- 513 A GPCR solved structures allowed the scientific 514 community to recognize some common features 515 that are crucial for their operability (Levit et al. 516 2014); however, these studies also revealed an 517 unexpected heterogeneity and complexity in 518 GPCR recognition, challenging the classical 519 pharmacology paradigms of the 'monogamous' 520 interaction between a specific class of natural 521 ligands and a single GPCR (Haupt et al. 2013). 522 In line with the growing promiscuity of GPCRs, 523 ligand dependent transactivation has been 524 demonstrated for GPR17, already known as a 525 "dual" receptor: similarly to EBI2 (Hannedouche 526 et al. 2011; Liu et al. 2011a), and the CXC 527 chemokine receptor 2 (CXCR2) (Raccosta et al. 528 2013). Specifically, it was shown that, GPR17 529 could act as a molecular target for oxysterols, 530 oxidized derivative of cholesterol that, in the 531 CNS, are involved in activities not strictly 532 associated with cholesterol metabolism. Of 533 note, these activities are particularly relevant 534 for neurodegenerative disorders, including 535 demyelinating (Raccosta et al. 2013; Garenc 536 
et al. 2010). More in detail, three selected oxysterols (27-Hydroxycholesterol,

\section{7} $\alpha$-Hydroxycholesterol and 22R-Hydroxycholesterol) were tested in $1321 \mathrm{~N} 1$ cells stably expressing GPR17, showing that all the tested compounds were able to stimulate GTP $\gamma \mathrm{S}$ binding, in a concentration-dependent manner, with $\mathrm{EC}_{50}$ values of $4.99 \pm 0.78 \mathrm{nM}, 0.70 \pm 0.09 \mathrm{nM}$ and $0.21 \pm 0.03 \mathrm{nM}$, for 27-Hydroxycholesterol, $7 \alpha$-Hydroxycholesterol and 22R-Hydroxycholesterol, respectively.

Stimulus of cell membranes with different oxysterol concentrations after treatment with the purinergic ligand UDP-glucose showed a left-shift of the concentration-response curves or an enhancement of their maximal $\left[{ }^{35} \mathrm{~S}\right]$ GTP $\gamma \mathrm{S}$ binding stimulation, suggesting that these ligands may cooperate under neuroinflammatory conditions.

In parallel, the effect of different concentration of the GPR17 receptor antagonist cangrelor on oxysterol-stimulated $\left[{ }^{35} \mathrm{~S}\right] \mathrm{GTP} \gamma \mathrm{S}$ binding was evaluated, demonstrating that cangrelor can counteract GPR17 activation by oxysterols through a competitive mechanism, with $\mathrm{IC}_{50}$ values in a sub-nM range. These results are also in agreement with in silico data suggesting a common orthosteric molecular recognition mechanism for oxysterols and other small GPR17 ligands, despite different local arrangements in the TM binding site (Sensi et al. 2014).

Among other non-conventional ligands, further evidence showed that SDF-1, historically known as the endogenous ligand for CXCR4 and CXCR7 receptors, is able to transactivate GPR17 in vitro, specifically increasing the $\left[{ }^{35} \mathrm{~S}\right]$ GTP $\gamma \mathrm{S}$ binding to membrane of GPR17expressing cells, with affinity constant values of $0.14 \pm 0.03 \mathrm{nM}$. The effect of SDF-1 in modulating GPR 17 responses in vitro was further assessed in primary OPC cultures natively expressing GPR17. In this model, treatment with physiological concentrations of SDF-1 significantly increased the number of cells expressing the Myelin Basic Protein MBP com3 pared to control, thus accelerating OPC differen84 tiation towards a mature phenotype. The specific involvement of GPR17 in these effects was 585 unequivocally demonstrated by further 586 experiments showing that, in presence of the 587 GPR17 antagonist cangrelor, SDF-1 induced no 588 increases of either $\left[{ }^{35} \mathrm{~S}\right] \mathrm{GTP} \gamma \mathrm{S}$ binding to cell 589 membranes, or MBP-expression in OPC cultures. 590 Moreover, the mechanism by which GPR17 and 591 SDF-1 can directly interact to each other has 592 been predicted and extensively characterized in 593 silico through molecular modeling (Parravicini 594 et al. 2016).

These results are in line with literature data, 596 that propose a role of SDF-1 in orchestrating 597 OPC differentiation and maturation also via 598 CXCR4/CXCR7-axis ( $\mathrm{Li}$ et al. 2012; Patel et al. 599 2010; Carbajal et al. 2011).

Interestingly, not only GPR17, CXCR4 and 601 CXCR7, but also others chemokine receptors, 602 like CXCR2, have demonstrated roles in 603 regulating OPCs. As previously mentioned (see 604 Sect. 2.1), besides sharing the same ligands, 605 GPR17 and chemokine receptors are phylogen- 606 etically related to each other, and all participate 607 to CNS reparative responses. This raises the 608 hypothesis that, under neurodegenerative demy- 609 elinating conditions, oxysterols and other 610 pro-inflammatory ligands, such as SDF-1, act as 611 non-conventional molecules with a transversal 612 regulatory role, representing a conserved, 613 "unspecific" signaling mechanism, by which 614 emergency molecules synchronize multiple 615 receptors involved in inflammatory/immune 616 responses.

\subsubsection{New GPR17 Synthetic Ligands}

In 2009 and 2010, two papers reported the devel- 621 opment of a new FAC-MS binding method for 622 the analysis of GPCRs (Calleri et al. 2010; 623 Temporini et al. 2009). In this assay, UDP was 624 found to bind to GPR17 with a Kd value of 625 $1612.0 \pm 708 \mathrm{nM}$ that was very similar to the 626 Kd value (1140.0 nM) obtained by Ciana et al. 627 and Lecca et al. in the $\left[{ }^{35} \mathrm{~S}\right] \mathrm{GTP} \gamma \mathrm{S}$-binding 628 (Ciana et al. 2006; Lecca and Ceruti 2008). 629 This paper also unveiled a number of previously 630 unreported GPR17 ligands, some of which were 631 able to increase $\left[{ }^{35} \mathrm{~S}\right] \mathrm{GTP} \gamma \mathrm{S}$ binding, with 632 
633 potency values in the $\mu \mathrm{M}$ and sub-nM range. For 634 example, the ATP analogue 2-Phenylethynyla635 denosine- $5^{\prime}$-monophosphate Compound N. 4 636 behaved as a very potent agonist with an $\mathrm{EC}_{50}$ 637 value of $36 \mathrm{pM}$. In contrast, other ligands (e.g.: $\mathrm{N}$ $638{ }^{6}$-Benzoyl-2'-deoxyadenosine $3^{\prime}, 5^{\prime}$-Bis phos639 phate, referred by the authors as Compound 640 N. 12) did not induce any increase in $\left[{ }^{35} \mathrm{~S}\right]$ 641 GTP $\gamma \mathrm{S}$ binding, but counteracted stimulation 642 induced by UDP-glucose with an antagonist pro643 file and an affinity constant in the $\mathrm{nM}$ range 644 comparable to that reported for its analogue 645 derivative MRS2179. Both the newly identified 646 agonists and antagonists displayed similar 647 behavior in the FAC-MS binding assay (Calleri 648 et al. 2010). A comparison between these data 649 and $\left[{ }^{35} \mathrm{~S}\right] \mathrm{GTP} \gamma \mathrm{S}$ binding results have been also 650 reported in a recent review article on GPR17 651 (Marucci et al. 2016).
In the same year, an advanced in silico HM procedure combined with high-efficiency virtual screening of more than 120,000 compounds from the Asinex Platinum Collection (http://www. asinex.com/), a lead-like structural library, on the modeled receptor led to the selection of 5 chemically diverse molecules (the ASINEX compounds, see Fig. 3 for the chemical structure of one representative compound, 2-[[5-(2-Methoxyphenyl)-4-(4-methoxyphenyl)4H-1,2,4-triazol-3-yl]thio]-N-phenylpro-

panamide, also referred as ASN 1), that were completely unrelated to already known ligands. These compounds were tested in vitro in the $\left[{ }^{35} \mathrm{~S}\right]$ GTP $\gamma \mathrm{S}$ binding assay, revealing a sub-nM potency for GPR17 (Eberini et al. 2011) (see also below). None of these compounds could have been expected 'a priori' to act on GPR17, and all of them behaved as much more potent ligands than GPR17 endogenous activators (Eberini et al. 2011). Finally, in 2013, MDL29,951 was reported as an additional small molecule agonist at GPR17 (Hennen et al. 2013) (Fig. 3). In a variety of different heterologous expression systems, MDL29,951-stimulated GPR17 engaged the entire set of intracellular adaptor proteins for GPCRs: G proteins of the

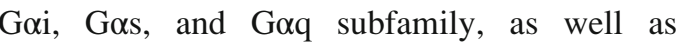
$\beta$-arrestins. This was visualized as alterations in the concentrations of cyclic adenosine 681 monophosphate and inositol phosphate, 682 increased $\mathrm{Ca}^{2+}$ flux, phosphorylation of ERK1/ 683 2 , as well as multifeatured cell activation 684 recorded with label-free dynamic mass redistri- 685 bution and impedance biosensors. pEC $_{50}$ values 686 for MDL29,951 at GPR17 ranged between 5 and 687 8.80 , depending upon the transfected cell type 688 and the used read out. MDL29,951-stimulated 689 GPR17 effects were counteracted in a 690 concentration-dependent manner by pranlukast 691 and, to a lesser extent, by montelukast. This is 692 fully in line with the activities of these 693 antagonists on recombinant GPR17 in previous 694 studies, in which pranlukast was significantly 695 more potent than montelukast in antagonizing 696 LTD4-stimulation of GPR17 (Ciana et al. 697 2006). In OPCs, MDL29,951 rapidly mobilized 698 intracellular $\mathrm{Ca}^{2+}$ in a concentration-dependent 699 manner and engaged both $G_{\alpha i}$ and $G_{\alpha q}$, but not 700 $\mathrm{G}_{\alpha \mathrm{s}}$ signaling pathways, further suggesting 701 differences in GPR17 responses between 702 transfected and native systems (see also 703 Conclusions). This is at variance from previous 704 studies reporting $G_{\alpha i}$ coupling and decreases of 705 intracellular cAMP as a primary transduction 706 pathway of GPR17 in OPCs (Daniele et al. 707 2014; Fumagalli et al. 2011b). However, it has 708 to be emphasized that, despite being selective for 709 GPR17 inside the "purine receptor cluster" 710 (Hennen et al. 2013), MDL29,951 also signifi- 711 cantly interacts with the glycinergic site of the 712 glutamate NMDA receptor (Salituro et al. 1992). 713 This may be at the basis of the ability of 714 MDL29,951 to activate multiple signaling 715 pathways in both transfected cells and in OPCs, 716 and of the data reported for this compound on 717 myelination (see also Sect. 3.1.1).

\subsubsection{Agonist-Induced Desensitization 799 and Internalization

In 2011, the first complete agonist-induced 723 GPR17 desensitization/resensitization study was 724 published (Daniele et al. 2011). By using $\left[{ }^{35} \mathrm{~S}\right] 725$ GTP $\gamma \mathrm{S}$ binding and cAMP measurements in 726 $1321 \mathrm{~N} 1$ cells expressing hGPR17, both 727 UDP-glucose and $\mathrm{LTD}_{4}$ were shown to induce a 728 time- and concentration-dependent loss of 729 
GPR17 response (homologous desensitization). GPR17 homologous desensitization was accompanied by internalization of receptors inside cells, as assessed by biotin labeling of cell surface receptors. Desensitization occurred in a time-dependent manner, with similar kinetics for both agonists. Upon agonist removal, receptor resensitization occurred with the typical kinetics of GPCRs. Finally, activation of GPR17 by UDP-glucose induced a partial heterologous desensitization of $\mathrm{LTD}_{4}$-mediated responses (but not vice versa), suggesting that nucleotides have a hierarchy in producing desensitizing signals.

The pattern of GPR17 desensitization and internalization was fully confirmed and further expanded in differentiated oligodendroglial Oli-neu cells that natively express GPR17 (Fratangeli et al. 2013) (Table 1). Agonistinduced internalization, intracellular trafficking and membrane recycling of GPR17 were analyzed by biochemical and immunofluorescence assays using an ad hoc-developed new antibody against the extracellular N-terminal of GPR17. Both UDP-glucose and $\mathrm{LTD}_{4}$ increased GPR17 internalization, although with different efficiency. At early time points, internalized GPR17 co-localized with transferrin receptor, whereas at later times it partially co-localized with the lysosomal marker Lamp1, suggesting that a portion of GPR17 is targeted to lysosomes upon ligand binding. Internalization of GPR17 occurred via clathrin-dependent endocytosis (Fratangeli et al. 2013). Analysis of receptor recycling and degradation demonstrated that a significant fraction of GPR17 is recycled to the cell surface. These results provided the first data on the agonist-induced trafficking of native GPR17 in oligodendroglial cells and may have implications in fine-tuning cell responses to demyelinating and inflammatory conditions when these ligands accumulate at lesion sites (see also Sect. 3.1.2). More recently, GPR17 downregulation by uracil nucleotides and cysLTs was confirmed in primary cultured OPCs, and the role of the GRK/ $\beta$-arrestin machinery in receptor desensitization and intracellular signaling was also extensively investigated (Daniele et al. 2014). It was shown that, following OPCs treatment with the two classes of purinergic and 778 cysLT ligands, different GRK isoforms were 779 recruited. Specifically, cysLT-mediated GPR17 780 desensitization mainly involved GRK2 via a G 781 protein-dependent mechanism (Daniele et al. 782 2014). This kinase promoted transient binding 783 of the receptor to $\beta$-arrestins, rapid ERK phos- 784 phorylation and sustained nuclear CREB activa- 785 tion. Furthermore, GRK2, whose expression 786 paralleled that of the receptor during the differ- 787 entiation process, was required for cysLT- 788 mediated OPCs maturation (see also Sect. 3.2.). 789 On the other hand, purinergic ligands exclusively 790 recruited GRK5 via a G protein- 791 independent $/ \beta$-arrestin-dependent mechanism. 792 This kinase induced a stable association between 793 the receptor and $\beta$-arrestin, followed by slower 794 and sustained ERK stimulation and marginal 795 CREB activation (Daniele et al. 2014). These 796 results show that, through activation of GPR17 797 and recruitment of specific GRK isoforms, 798 purinergic and cysLT ligands engage distinct 799 intracellular pathways.

Recently GPR17 desensitization (and its rela- 801 tionship to terminal OPC maturation) has been 802 linked to activation of mTOR (the "mammalian 803 target of rapamycin"), which has long been 804 known to be involved in myelination. During 805 OPC differentiation, mTOR regulates 806 GRK-mediated desensitization of GPR 17 by pro- 807 moting the nuclear translocation of the ubiquitin 808 ligase MDM2, which had been previously only 809 involved in cancer via regulation of p53 activity 810 and now emerges as a new interesting actor in 811 oligodendrogenesis (Fumagalli et al. 2015). Spe- 812 cifically, treatment of OPCs with either the 813 mTOR inhibitor rapamycin, or with nutlin-3, a 814 small molecule inhibitor of Mdm2-p53 815 interactions, was shown to keep MDM2 in the 816 cytosol, where it could bind to GRK2 and sustain 817 its degradation, thus impairing the physiological 818 desensitization of GPR17 (Fumagalli et al. 819 2015). Important, prevention of GPR17 desensi- 820 tization was also associated to a defect of OPC 821 maturation, confirming that aberrantly elevated 822 GPR17 levels in late stage OPCs blocks cells at 823 immature stages (Fumagalli et al. 2015). 
867 In the healthy intact brain, GPR17 expression is 868 predominantly in oligodendrocyte (OL) cells. 869 The very first demonstration that, in the adult brain, GPR17 is highly expressed by a 870 sub-population of endogenous quiescent paren- 871 chymal OPCs dates back to 2008 (Lecca et al. 872 2008) and has sparked a lot of interest on GPR17 873 role in CNS myelination. Specifically, GPR17 874 was shown to be present in ramified early neural 875 cell precursors dispersed throughout brain's gray 876 and white matter that also positively stained for 877 typical early OPC markers. Since then, increas- 878 ing evidence has progressively accumulated to 879 show a pivotal role of GPR17 in OPC matura- 880 tion, with different and apparently paradoxical 881 effects during different phases of the maturation 882 process (Chen et al. 2009; Fumagalli et al. 883 2011a) (see also below).

In vitro studies on purified rat postnatal OPC 885 cultures showed that GPR17 expression 886 coincides with a specific temporal window of 887 the OL differentiation process. It covers two 888 distinct phases: a first phase, during which early 889 differentiation markers like NG2, A2B5, PDGF 890 receptor-alpha and the immature PLP isoform 891 DM-20 are still present (early stage 2 OPCs in 892 Fig. 4), and a subsequent phase characterized by 893 more ramified, still immature 894 pre-oligodendrocytes (stages 3 and 4 in Fig. 4), 895 where NG2 has been downregulated and more 896 advanced markers like O4, O1 and the 897 proteolipid myelin protein PLP are present 898 (Fumagalli et al. 2011a). Based on these data, 899 GPR17 is currently utilized by other independent 900 scientists to specifically label pre-immature OLs 901 at these two transition stages (Mitew et al. 2013; 902 Nakatani et al. 2013; Crociara et al. 2013; Ferrara 903 et al. 2016).

Of note, GPR17 expression progressively 905 increases during the transition of OPCs to 906 pre-OLs (when it is maximally expressed in cel- 907 lular processes), but is then gradually silenced 908 and never found in fully morphologically mature 909 OLs (Fumagalli et al. 2011a) (see Fig. 4). 910 Accordingly, in vivo, GPR17 is present in a sub- 911 set of NG2/Olig2-positive OPCs expressing the 912 first myelin proteins, but not in more mature cells 913 expressing myelin basic protein (MBP). Also 914 during rodent brain development, GPR17 expres- 915 sion in OPCs precedes myelin production. Inter- 916 estingly, GPR17 immunoreactivity appears first 917 


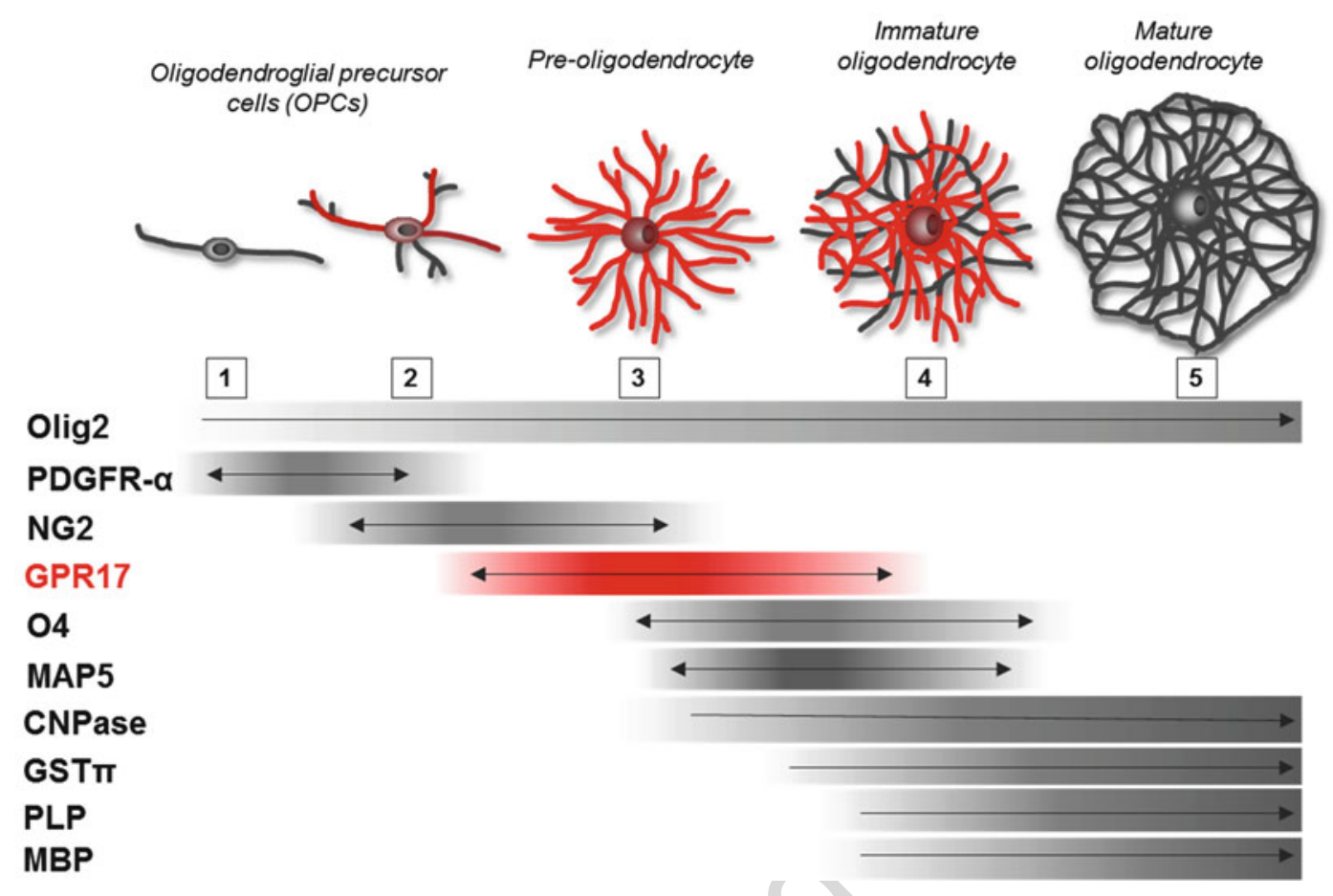

Fig. 4 Transient GPR17 expression during oligodendroglial differentiation. The expression pattern of GPR17 (in red) during oligodendroglial differentiation is shown in parallel to other known oligodendroglial markers (other colours). Progressive differentiation stages are indicated with numbers from 1 to 5 . From a functional

in the cell body, partially coinciding with 919 markers of the Golgi apparatus, and then gradu920 ally extends to cellular processes (Boda et al.
2011). Early after birth, the expression of the receptor is low, but progressively expands to cover the $80 \%$ of OPCs at the end of the third week of life. Afterwards, GPR17 is downregulated while myelination proceeds (Boda et al. 2011).

The transient nature of GPR17 expression in OPCs suggests that the receptor may display stage-specific roles during OL development. Intriguingly, as already reported for the Wnt/ $\beta$-catenin pathway (Fancy et al. 2009; Ye et al. 2009) and more recently proposed for the transcription factor Olig2 (Mei et al. 2013), GPR17 exhibits opposing functions on OL differentiation in relation to its expression stage. In cultured cortical postnatal rat OPCs, early receptor obliteration with small interfering RNAs point of view, GPR17 exerts opposing stage-specific roles: a positive role for differentiation in early OPCs and a negative function for OL maturation in late OPCs. In late OPCs, gradual silencing of GPR17 is needed to allow OPCs to complete their maturation (see text for more details)

profoundly affected their ability to generate 938 mature OLs, suggesting that cells are retained at 939 a less differentiated stage (Fumagalli et al. 940 2011a) (Fig. 4). Although the molecular 941 mechanisms at the basis of these events have 942 not been yet investigated, these data highlight a 943 pivotal role of GPR17 in the initial phases of the 944 differentiation process. They support the hypoth- 945 esis that, at these stages, GPR17 may be impor- 946 tant to keep cells at an immature state which 947 may, in turn, be necessary to prepare them for 948 myelination (Fumagalli et al. 2011a). In contrast, 949 cultured cortical progenitors from GPR17 knock- 950 out E15.5 mouse embryos differentiated earlier 951 toward mature OLs compared to control cells 952 (Chen et al. 2009). The reasons for these 953 discrepancies remain unknown, although it may 954 be hypothesized that compensatory mechanisms 955 are activated as a result of early embryonic 956 GPR17 knock out. Of course, the generation of 957 

1000 ligands accumulating in the extracellular milieu: 1001 activation of early OPCs (stages 2 and 3 in Fig. 4) 1002 with GPR17 endogenous putative ligands (i.e., 1003 UDP-glucose or $\mathrm{LTD}_{4}$ ) indeed promoted conver1004 sion to more mature cells expressing myelin markers (Lecca et al. 2008; Fumagalli et al. 1005 2011a; Ceruti et al. 2011). Consistent with these 1006 data, GPR17 antagonists like cangrelor (Fig. 3) 1007 delayed the ability to generate mature cells 1008 (Lecca et al. 2008; Fumagalli et al. 2011a), 1009 suggesting that GPR17 endogenous ligands are 1010 basally released in culture and are responsible for 1011 the observed spontaneous OPC in vitro matura- 1012 tion. In another independent study, while not 1013 modifying the potential of adult multipotent neu- 1014 ral stem cells, montelukast, which also acts as a 1015 GPR17 antagonist (Ciana et al. 2006; Benned- 1016 Jensen and Rosenkilde 2010; Lecca et al. 2008), 1017 markedly increased their proliferation rate, 1018 suggesting that GPR17 antagonism induces 1019 retention of cells at a more undifferentiated 1020 stage (Huber et al. 2011).

As already mentioned, besides cAMP inhibi- 1022 tion, GPR 17 has been also shown to specifically 1023 mediate activation of delayed rectifier $\mathrm{K}^{+} 1024$ currents (Table 1) in a sub-population of OPCs 1025 and $\mathrm{O}^{+}$pre-OLs, but not in mature OLs. This 1026 effect was shown to contribute to the terminal 1027 maturation of OPCs and to their migratory 1028 abilities.

In contrast with the above studies, 1030 MDL29,951, the new putative GPR17 agonist 1031 mentioned above, was reported to inhibit, rather 1032 than stimulate, OL maturation (Hennen et al. 1033 2013). However, it is worth to note that, due to 1034 the transient expression of GPR17 in culture, the 1035 timing of OPC manipulation and treatment is 1036 crucial for obtaining comparable results. On the 1037 other hand, as already mentioned, MDL29,951 is 1038 not a selective ligand for this receptor, and inde- 1039 pendent effects could be due to its antagonistic 1040 activity at the glycinergic site of the glutamate 1041 NMDA receptor (Salituro et al. 1992), which has 1042 been indeed reported to promote OPC differenti- 1043 ation (Li et al. 2013). 1044

Globally, these findings suggest that GPR17 1045 exerts opposing stage-specific roles: a positive 1046 role for differentiation in early OPCs and a nega- 1047 tive function for OL maturation in late OPCs. 1048 They also suggest that, in late OPCs, physiologi- 1049 cal GPR17 silencing is needed to allow cells to 1050 complete their maturation program. The latter 1051 
1052 may occur via either GPR17 desensitization/ 1053 internalization by endogenous agonists or by 1054 GPR17-mediated engagement of intracellular 1055 pathways culminating in nuclear events, or 1056 both. Blockade of GPR17 mRNA translation 1057 into the receptor protein a specific microRNA 1058 has been also recently reported to contribute to 1059 GPR17 regulation during OPC maturation 1060 (Lecca et al. 2016).

\section{3.1.2 Dysregulation in Demyelinating $1062 \quad$ Neurodegenerative Diseases}

1065 The demonstration that levels of endogenous 1066 nucleotides and cysLTs are massively increased 1067 upon CNS trauma and ischemia and their 1068 hypothesized roles as danger signals after injury 1069 (Davalos et al. 2005; Haynes et al. 2006) has 1070 raised the hypothesis that GPR17 may act as a 1071 crucial mediator of reactivity to acute injury. 1072 While physiologically GPR17 is mostly an 1073 oligodendroglial receptor, after acute injury, 1074 GPR17 is sequentially induced in dying neurons 1075 inside and at the borders of the ischemic/trau1076 matic lesion, in infiltrating microglia/ 1077 macrophages and in activated parenchymal 1078 OPCs in the lesion's surrounding areas, with 1079 similar expression patterns in different models 1080 of pathology. In more detail, in both rats and 1081 mice, $24 \mathrm{~h}$ after permanent middle cerebral artery 1082 occlusion (MCAo), GPR17 is up-regulated in 1083 neurons damaged by the ischemic insult inside 1084 the ischemic core (Ciana et al. 2006; Lecca et al. 1085 2008). When the penumbra area is well visible 1086 and most of the neurons in the core are dead, 1087 GPR17 appears on highly activated microglia 1088 and blood-borne macrophages at the borders of 1089 the lesion (Lecca et al. 2008). This has been 1090 independently confirmed to also occur in a tran1091 sient MCAo rodent model, where the number of 1092 GPR17 expressing cells was significantly 1093 upregulated in two distinct phases, $24 \mathrm{~h}$ and 10947 days after reperfusion, consistent with an 1095 early acute neuronal injury followed by a late 1096 microgliosis (Zhao et al. 2012). It is known that 1097 OPCs are extremely sensitive to the pathophysi1098 ological state of the brain, and that they react to 1099 many different types of experimentally induced 1100 insults. Starting from $72 \mathrm{~h}$ after the insult, in the regions surrounding the ischemic area and in the 1101 ipsilateral corpus striatum of MCAo mice, a 1102 higher number of GPR17-expressing OPCs was 1103 indeed found compared to contralateral hemi- 1104 sphere (Lecca et al. 2008), suggesting an 1105 increased proliferation rate in response to 1106 demyelination. 1107

Dysregulated expression of GPR17 has been 1108 described also after traumatic injury, in both 1109 brain (Boda et al. 2011) and spinal cord (Ceruti 1110 et al. 2009). In stab wound, a model of cortical 1111 trauma, early after lesion, the density of GPR17- 1112 expressing OPCs in gray matter was reduced 1113 compared to contralateral cortex, consistent 1114 with a global oligodendroglial loss. At later 1115 times, GPR $17^{+}$cells increased significantly in 1116 number around the lesion in both gray and 1117 white matter, likely due to the expansion of the 1118 NG2 cell pool, which, in turn, reflects an attempt 1119 to replace dead OPCs. This reactivity lasted up to 1120 7 days and then declined over time, going back to 1121 basal levels at 14 days after lesion. This pattern 1122 has been confirmed in human samples from 1123 patients with traumatic brain injury (Franke 1124 et al. 2013). In both neurosurgical and autopsy 1125 specimens, GPR17 expression was evident inside 1126 the contused core and progressively declined 1127 distally according to a spatio-temporal gradient. 1128 Inside and around the core, GPR17 labeled dying 1129 neurons, reactive astrocytes, and activated 1130 microglia/macrophages. In peri-contused paren- 1131 chyma, GPR17 was found on OPCs, some of 1132 which had proliferated, indicating 1133 re-myelination attempts. In agreement with the 1134 above data, in a double transgenic model of 1135 Alzheimer's disease (the APPPS1 mouse) a 1136 high number of GPR17-positive cells 1137 accumulated close to amyloid plaques in gray 1138 matter, revealing receptor up-regulation as a fea- 1139 ture of oligodendroglial reactivity also in this 1140 pathological condition (Boda et al. 2011). 1141

Similar GPR17 changes have been reported 1142 also in typically de-myelinating diseases such as 1143 in models of multiple sclerosis (MS). In this 1144 disease, remyelination occurs after the initial 1145 myelin damage, but it fails after multiple demye- 1146 lination episodes, which eventually leads to axo- 1147 nal degeneration and progressive disability 1148 
1149 (Franklin and Ffrench-Constant 2008). Interest1150 ingly, synthesis of cysLTs is increased in MS 1151 plaques and in the spinal cord of mice subjected 1152 to experimental autoimmune encephalomyelitis 1153 (EAE), an immune-mediated model of demyelin1154 ation (Whitney et al. 2001). Of note, 1155 montelukast, an antagonist at both CysLT1 and 1156 GPR17, attenuated CNS infiltration of inflamma1157 tory cells and the clinical symptoms of EAE 1158 (Wang et al. 2011). However, the exact contribu1159 tion of GPR17 to these effects has not been 1160 investigated in detail. Overexpression of the 1161 GPR17 transcript has been observed in both 1162 EAE mice and in a cohort of human MS tissues 1163 (Chen et al. 2009). GPR17 expression was sig1164 nificantly increased in MS plaques as compared 1165 with white matter from non-neurological donor 1166 samples and normal-appearing white matter from 1167 MS donors. In a similar way, acute damage to 1168 myelin induced by lysolecithin (Lys) injection in 1169 corpus callosum induced a strong overexpression 1170 of GPR 17 at the lesion site 10 days after injury 1171 (Boda et al. 2011). Thus, independently of the 1172 original cause, GPR17 is abnormally 1173 up-regulated in MS and some models of neuro1174 degenerative conditions characterized by myelin 1175 disruption (Fumagalli et al. 2016).

1176 On this basis, it could be hypothesized that, 1177 after damage, GPR17 is initially induced to pro1178 mote the growth and differentiation of OPCs; 1179 however, at later stages, due to lack of appropri1180 ate environmental stimuli, presence of inflamma1181 tory signals and/or intrinsic factors, 1182 physiological GPR17 downregulation is 1183 impeded, thus freezing cells at a stand-by stage, 1184 where they are neither proliferating nor 1185 differentiating. When this happens, interventions 1186 targeting GPR17 may help bypassing this check1187 point and facilitate terminal maturation. Since 1188 GPR17 is a membrane receptor that, at variance 1189 from other intrinsic regulators of oligoden1190 drogenesis, can be easily targeted and 1191 manipulated with pharmacological agents, it is 1192 envisaged that agents counteracting GPR17 aber1193 rant expression under these conditions could 1194 induce OPCs to resume myelination and promote 1195 neurorepair. To support this hypothesis, in 1196 MCAo animals, administration of GPR17 antagonists such as cangrelor or montelukast 1197 (Ciana et al. 2006; Lecca et al. 2008), or 1198 GPR17 silencing due to in vivo delivery of spe- 1199 cific antisense oligonucleotides (Ciana et al. 1200 2006; Lecca et al. 2008) or small interfering 1201 RNAs (Zhao et al. 2012) resulted in a significant 1202 reduction in brain's ischemic volume. Use of 1203 GPR17 anti-sense oligonucleotides also reduced 1204 damage and improved functional recovery in a 1205 model of spinal cord injury, in line with the 1206 hypothesis that GPR17 is aberrantly 1207 overexpressed as a consequence of damage 1208 (Ceruti et al. 2009). 1209

In contrast to what observed in MCAo, in a rat 1210 neonatal model of ischemic periventricular 1211 leukomalacia (PVL), a common cerebral white 1212 matter injury, the GPR17 agonist UDP-glucose 1213 (and not an antagonist) significantly contributed 1214 to myelin sheaths recovery and improved motor 1215 functions, learning and coordination in PVL pups 1216 (Mao et al. 2012). The reason for this discrep- 1217 ancy may reside in the different outcome of the 1218 ischemic insult in neonatal brain compared to 1219 adults. It could be hypothesized that, in neonatal 1220 pups, existing OPCs, which are very sensitive to 1221 ischemic death, are immediately killed by the 1222 ischemic insult, with no obvious GPR17 1223 upregulation; conversely, being these cells 1224 generated at distinct waves during the first 1225 weeks of life at much higher rates compared to 1226 adulthood, a GPR17 agonist (instead of an antag- 1227 onist) would allow to properly activate newborn 1228 OPCs, thus favouring the formation of myelin 1229 sheaths and neurological recovery. 1230

Several of the still obscure aspects of GPR17 1231 pathophysiology have been linked to the diffi- 1232 culty of establishing a causal relationship 1233 between GPR17 expression and myelination 1234 in vivo. Since GPR17 is no longer expressed in 1235 mature myelinating OLs (Lecca et al. 2008; 1236 Fumagalli et al. 2015), it was impossible to dem- 1237 onstrate that cells that have expressed GPR17 in 1238 their earlier life can indeed myelinate. Only 1239 recently, the generation of the first 1240 GPR17iCreER $^{\mathrm{T} 2}$-GFP reporter mouse line for 1241 fate mapping studies has allowed to follow the 1242 final destiny of GPR $17^{+}$cells during both physi- 1243 ological differentiation and in disease, thanks to 1244 
1245 the inducible expression of the green fluores1246 cence protein (GFP). In these mice, upon tamox1247 ifen induced recombination, OPCs expressing 1248 GPR 17 at that very specific moment, become 1249 green and can be traced as such for the entire 1250 animal's like. Use of these mice has allowed to 1251 show that, in normal brain, $\mathrm{GFP}^{+}$cells differenti1252 ate very slowly (needing about 3 months to reach 1253 maturity), but after acute insults, they rapidly 1254 reacted to damage with proliferation and migra1255 tion toward the injured site, thus representing a 1256 'reserve pool' of adult quiescent progenitors 1257 maintained for repair purposes (Vigano et al. 1258 2016). A full characterization of the long-term 1259 events occurring in the brain of ischemic MCAo 1260 GPR17iCreER $^{\mathrm{T} 2}$-GFP mice has shown that, 1261 despite massive recruitment of $\mathrm{GFP}^{+}$green 1262 OPCs at the ischemic site, only a few percentage 1263 of these cells become mature myelinating OLs, 1264 likely due to local unfavourable inflammatory 1265 milieu (Vigano et al. 2016; Bonfanti et al. 2017). 1266 More recently, it has been demonstrated that 1267 GPR17 over-activation inhibited oligodendro1268 cyte survival by reducing intracellular cAMP 1269 levels and inducing expression of the 1270 pro-apoptotic gene Xafl. GPR17 overactivation 1271 also negatively regulated protein kinase A sig1272 naling pathway and expression of the transcrip1273 tion factor c-Fos. In line with these data, in the 1274 lysolecithin-mediated demyelination injury 1275 model, the pharmacological inhibition of 1276 GPR17 with pranlukast increased oligodendro1277 cyte survival and promoted immature oligoden1278 drocyte differentiation through the upregulation 1279 of Epac1, the exchange factor directly activated 1280 by cAMP (Ou et al. 2016). These data are fully 1281 consistent with our results in other injury models 1282 characterized by demyelination and abnormal 1283 GPR17 upregulation (summarized in Fumagalli 1284 et al. 2016), suggesting that under these 1285 conditions GPR17 inhibition has potential for 1286 treatment of demyelinating diseases (Ou et al. 1287 2016).

\subsection{GPR17 in Brain Rejuvenation}

A recent report has investigated the roles of 1289 GPR17 in age-associated cognitive decline 1290 (Marschallinger et al. 2015). Authors have first 1291 shown that oral administration of montelukast 1292 (an antagonist of both CysLTR1 and GPR17, 1293 see above), for 6 weeks to moderately old rats 1294 (20 months old) resulted in structural and func- 1295 tional rejuvenation of aged brains, as 1296 demonstrated by restoration of blood brain bar- 1297 rier integrity, reduced microglia activation in the 1298 brain, increased levels of hippocampal 1299 neurogenesis and significantly improved learning 1300 and memory tasks. Important, montelukast had 1301 no effects on the behaviour and cognitive 1302 abilities of young animals, suggesting that its 1303 actions specifically target an aging associated 1304 defect (see also below). Regression and correla- 1305 tion analyses showed that montelukast-induced 1306 learning improvement in the old animals was 1307 independent of the changes in microglia mor- 1308 phology but rather depended on the rate of 1309 neurogenesis measured as increased number of 1310 proliferating neuroblasts in hippocampal dentate 1311 gyrus. Interestingly, authors also provided immu- 1312 nohistochemical evidence for the presence of 1313 GPR17, but not CysLTR1, in a subset of 1314 doublecortin $(\mathrm{DCX})^{+}$newborn neurons in hippo- 1315 campal dentate gyrus, suggesting a role in the 1316 proliferation and specification of these cells. 1317 Studies on neurospheres obtained from mice 1318 lacking FOXO1, a GPR17 regulating transcrip- 1319 tion factor, and from GPR $17^{-/-}$mice indeed 1320 confirmed montelukast effects be due to action 1321 on GPR17/DCX ${ }^{+}$neuroblasts in hippocampal 1322 dentate gyrus, leading to increased neurogenesis. 1323 Globally these data suggest that, under normal 1324 conditions, GPR17 exerts a negative control on 1325 the proliferation of neural progenitors in the hip- 1326 pocampus; in aged animals, due to the overall 1327 decrease of neurogenesis, GPR17 inhibition of 1328 proliferation becomes detrimental and 1329 contributes to memory impairment. Under such 1330 pathological conditions, montelukast can restore 1331 neurogenesis by alleviating GPR17 inhibitory 1332 effect (Marschallinger et al. 2015). 


\section{3.3 GPR17 in Gliomas}

1335 OL markers such as Olig2, PDGFR $\alpha$ and NG2 1336 are often expressed in glioma cells. Little is 1337 known about the origin of these tumors, but it is 1338 possible that they arise from dysregulated OPCs 1339 (Liu et al. 2011b). Considering that OPCs are the 1340 only proliferating population in the adult brain, 1341 defects in differentiation mechanisms favouring 1342 cell proliferation could be a primary cause of 1343 gliomas. A complementary strategy for tumor 1344 treatment is to promote pathways for maintaining 1345 quiescence and/or driving terminal differentia1346 tion of the tumoral progenitors. In this respect, 1347 a recent microarray analysis of mouse and human 1348 gliomas aimed at unveiling new candidates pro1349 moting differentiation or quiescence has 1350 highlighted GPR17 as a new potential target 1351 (Dougherty et al. 2012). In glioma cells, treat1352 ment with UDP, UDP-glucose or $\mathrm{LTD}_{4}$ indeed 1353 reduced the formation of glioma spheres 1354 suggesting that GPR17 stimulation can represent 1355 a good strategy to drive the differentiation of 1356 highly proliferative uncommitted tumor cells to 1357 the oligodendroglial fate, negatively affecting 1358 both tumor cell proliferation and self-renewal 1359 (Dougherty et al. 2012). These data are in line 1360 with the fact that most of the OPCs expressing 1361 GPR17 in brain are quiescent (Lecca et al. 2008), 1362 and support the pro-differentiative effects of its 1363 putative endogenous ligands (see also Sects. 2.1 1364 and 3.2).

\section{Conclusions}

1366 GPR17 has emerged as a new GPCR of great 1367 interest for drug development. It is almost exclu1368 sive localization to OPCs, the myelin forming 1369 cells and the only (slowly) proliferating cell pop1370 ulation in the intact brain, has highlighted 1371 GPR17 as a novel pharmacological target for 1372 demyelinating diseases. At variance from other 1373 myelinating genes, GPR17 is a membrane recep1374 tor, thus amenable for pharmacological modula1375 tion, which has attracted a lot of interest for the 1376 development of new therapeutic approaches to
MS and other neurodegenerative diseases 1377 characterized by myelin disruption. The recent 1378 demonstration that GPR17 is also expressed by a 1379 subset of hippocampal neural progenitors 1380 involved in cognitive functions does not detract 1381 from the potential interest of GPR17 ligands in 1382 neurodegenerative diseases, since, as 1383 demonstrated by the montelukast study 1384 (Marschallinger et al. 2015), these ligands may 1385 be active only when specific pathological GPR17 1386 changes are present.

The recent studies on GPR17 revealed its 1388 transient expression in OPCs and a more com- 1389 plex role than expected: a pro-differentiating role 1390 in early OPCs and a negative function on matu- 1391 ration in late stage OPCs. Thus, the apparently 1392 contrasting in vitro data obtained with different 1393 GPR17 stimulatory agents (Lecca et al. 2008; 1394 Fumagalli et al. 2011a; Hennen et al. 2013) 1395 may depend on the specific differentiation stage 1396 at which these compounds have been added to 1397 cultured OPCs. It may well be that the function 1398 of GPR 17 is different in the intact and diseased 1399 brain, based on the availability of its endogenous 1400 ligands. If uracil nucleotides, cysLTs, oxysterols 1401 and chemokines like SDF-1 are indeed among 1402 the signaling molecules able to activate GPR17 1403 in vivo (see also below), we envisage that their 1404 role would be more likely unveiled under patho- 1405 logical conditions, where these ligands massively 1406 accumulate at lesion sites inside the CNS. $\quad 1407$

Experiments in a wide variety of rodent 1408 models of neurodegeneration have shown that, 1409 independently of the nature of the insult (ische- 1410 mic, traumatic or toxic) and of the presence of 1411 any concomitant neuronal pathology, demyelin- 1412 ating conditions invariably led to GPR17 1413 upregulation. We believe that this dysregulation 1414 reflects an initial attempt to repair the lesion by 1415 stimulating OPCs differentiation via GPR17, but 1416 that this attempt is later invalidated by the inabil- 1417 ity of maturing cells to downregulate/internalize 1418 the receptor, which, in turn, leads a differentia- 1419 tion blockade. On this basis, it is envisaged that 1420 GPR17 antagonists would be useful in MS and 1421 neurodegenerative diseases. By counteracting 1422 GPR17 aberrant dysfunction, antagonists would 1423 help OPCs to complete their maturation, thus 1424 
1425 re-establishing endogenous remyelination, as 1426 recently also confirmed (Ou et al. 2016).

1427 Due to the still ambiguous state of the phar1428 macology for this receptor, the Nomenclature 1429 Committee of the International Union of Phar1430 macology (NC-IUPHAR) has not yet officially 1431 de-orphanized this GPCR (Davenport et al. 1432 2013). However, as also emphasized by 1433 NC-IUPHAR, much of the work in this area has 1434 been based on recombinant expression systems 1435 using different host cells and transfection 1436 methodologies compared to data derived from 1437 native cells. In recombinant "artificial" cell 1438 systems, activity tests are highly dependent on 1439 the experimental conditions utilized and subject 1440 to several artifacts, especially in the case of 1441 receptors' constitutive activation, a typical fea1442 ture of several GPCRs including GPR17 1443 (Benned-Jensen and Rosenkilde 2010; Maekawa 1444 et al. 2009; Qi et al. 2013; Eggerickx et al. 1995; 1445 Uhlenbrock et al. 2002; Rosenkilde et al. 2006; 1446 Qin et al. 2011; Im 2004) that can profoundly 1447 alter ligand behavior (Kenakin 2001; Davenport 1448 et al. 2013).

1449 In terms of drug development, neither uracil 1450 nucleotides nor CysLTs are suitable to this pur1451 pose, because neither ligand class is competent to 1452 discriminate between the functions of purinergic 1453 receptors, CysLT receptors, and GPR17 in vivo, 1454 where multiple receptors are often co-expressed. 1455 Nevertheless, the already available in vivo rodent 1456 data reporting positive neuro-reparative effects 1457 induced by commercially available montelukast 1458 or pranlukast ( $\mathrm{Yu}$ et al. 2005a, b), which are 1459 potent (although non selective) GPR17 1460 antagonists, foster the search for further GPR17 1461 ligands (Eberini et al. 2011; Hennen et al. 2013) 1462 and may represent an important advancement for 1463 patients with neurodegenerative diseases.

1464 Acknowledgements Authors are deeply grateful to the 1465 Italian Multiple Sclerosis (FISM) for financial support 1466 (Projects N. 2013/R1 to MPA) and to Cariplo Foundation 1467 (Projects 2014-1207 to DL and 2015-0910 to MF).

1468 Conflicts of Interest The authors declare no conflicts of 1469 interest.

\section{References}

Abbracchio MP, Burnstock G, Boeynaems JM, Barnard 1471 EA, Boyer JL, Kennedy C, Knight GE, Fumagalli M, 1472 Gachet C, Jacobson KA, Weisman GA (2006) Inter- 1473 national Union of Pharmacology LVIII: update on the 1474 P2Y G protein-coupled nucleotide receptors: from 1475 molecular mechanisms and pathophysiology to ther- 1476 apy. Pharmacol Rev 58(3):281-341 1477

Benned-Jensen T, Rosenkilde MM (2010) Distinct 1478 expression and ligand-binding profiles of two consti- 1479 tutively active GPR17 splice variants. Br J Pharmacol 1480 159(5):1092-1105

1481

Blasius R, Weber RG, Lichter P, Ogilvie A (1998) A 1482 novel orphan $G$ protein-coupled receptor primarily 1483 expressed in the brain is localized on human chromo- 1484 somal band 2q21. J Neurochem 70(4):1357-1365 1485

Boda E, Vigano F, Rosa P, Fumagalli M, Labat-Gest V, 1486 Tempia F, Abbracchio MP, Dimou L, Buffo A (2011) 1487 The GPR17 receptor in NG2 expressing cells: focus 1488 on in vivo cell maturation and participation in acute 1489 trauma and chronic damage. Glia 59(12):1958-1973 1490

Bonfanti E, Gelosa P, Fumagalli M, Dimou L, Viganò F, 1491 Tremoli E, Cimino M, Sironi L, Abbracchio MP 1492 (2017) The role of oligodendrocyte precursor cells 1493 expressing the GPR17 receptor in brain remodelling 1494 after stroke. Cell Death Dis [in press] 1495

Brink C, Dahlen SE, Drazen J, Evans JF, Hay DW, 1496 Nicosia S, Serhan CN, Shimizu T, Yokomizo T 1497 (2003) International Union of Pharmacology 1498 XXXVII. Nomenclature for leukotriene and lipoxin 1499 receptors. Pharmacol Rev 55(1):195-227 1500

Buccioni M, Marucci G, Dal Ben D, Giacobbe D, 1501 Lambertucci C, Soverchia L, Thomas A, Volpini R, 1502 Cristalli G (2011) Innovative functional cAMP assay 1503 for studying G protein-coupled receptors: application 1504 to the pharmacological characterization of GPR17. 1505 Purinergic Signal 7(4):463-468 1506

Calleri E, Ceruti S, Cristalli G, Martini C, Temporini C, 1507 Parravicini C, Volpini R, Daniele S, Caccialanza G, 1508 Lecca D, Lambertucci C, Trincavelli ML, Marucci G, 1509 Wainer IW, Ranghino G, Fantucci P, Abbracchio MP, 1510 Massolini G (2010) Frontal affinity chromatography- 1511 mass spectrometry useful for characterization of new 1512 ligands for GPR17 receptor. J Med Chem 531513 (9):3489-3501

1514

Capra V, Ravasi S, Accomazzo MR, Citro S, Grimoldi M, 1515 Abbracchio MP, Rovati GE (2005) CysLT1 receptor is 1516 a target for extracellular nucleotide-induced heterolo- 1517 gous desensitization: a possible feedback mechanism 1518 in inflammation. J Cell Sci 118(Pt 23):5625-5636 1519

Carbajal KS, Miranda JL, Tsukamoto MR, Lane TE 1520 (2011) CXCR4 signaling regulates remyelination by 1521 endogenous oligodendrocyte progenitor cells in a viral 1522 model of demyelination. Glia 59(12):1813-1821 1523

Ceruti S, Villa G, Genovese T, Mazzon E, Longhi R, 1524 Rosa P, Bramanti P, Cuzzocrea S, Abbracchio MP 1525 (2009) The P2Y-like receptor GPR17 as a sensor of 1526 
1527 damage and a new potential target in spinal cord 1528 injury. Brain 132(Pt 8):2206-2218

1529 Ceruti S, Vigano F, Boda E, Ferrario S, Magni G, 1530 Boccazzi M, Rosa P, Buffo A, Abbracchio MP 1531 (2011) Expression of the new P2Y-like receptor 1532 GPR17 during oligodendrocyte precursor cell matura1533 tion regulates sensitivity to ATP-induced death. Glia 1534 59(3):363-378

1535 Chang JM, Di Tommaso P, Taly JF, Notredame C (2012) 1536 Accurate multiple sequence alignment of transmem1537 brane proteins with PSI-Coffee. BMC Bioinf 13(Suppl 1538 4):S1

1539 Chen Y, Wu H, Wang S, Koito H, Li J, Ye F, Hoang J, 1540 Escobar SS, Gow A, Arnett HA, Trapp BD, 1541 Karandikar NJ, Hsieh J, Lu QR (2009) The 1542 oligodendrocyte-specific $\mathrm{G}$ protein-coupled receptor 1543 GPR17 is a cell-intrinsic timer of myelination. Nat 1544 Neurosci 12(11):1398-1406

1545 Ciana P, Fumagalli M, Trincavelli ML, Verderio C, 1546 Rosa P, Lecca D, Ferrario S, Parravicini C, Capra V, 1547 Gelosa P, Guerrini U, Belcredito S, Cimino M, 1548 Sironi L, Tremoli E, Rovati GE, Martini C, 1549 Abbracchio MP (2006) The orphan receptor GPR17 1550 identified as a new dual uracil nucleotides/cysteinyl1551 leukotrienes receptor. EMBO J 25(19):4615-4627

1552 Coppi E, Maraula G, Fumagalli M, Failli P, Cellai L, 1553 Bonfanti E, Mazzoni L, Coppini R, Abbracchio MP, 1554 Pedata F, Pugliese AM (2013) UDP-glucose enhances 1555 outward $\mathrm{K}(+)$ currents necessary for cell differentia1556 tion and stimulates cell migration by activating the 1557 GPR17 receptor in oligodendrocyte precursors. Glia 1558 61(7):1155-1171

1559 Crociara P, Parolisi R, Conte D, Fumagalli M, Bonfanti L 1560 (2013) Cellular and molecular characterization of 1561 multipolar Map5-expressing cells: a subset of newly 1562 generated, stage-specific parenchymal cells in the 1563 mammalian central nervous system. PLoS One 8(5): 1564 e63258

1565 Daniele S, Lecca D, Trincavelli ML, Ciampi O, 1566 Abbracchio MP, Martini C (2010) Regulation of 1567 PC12 cell survival and differentiation by the new 1568 P2Y-like receptor GPR17. Cell Signal 22(4):697-706 1569 Daniele S, Trincavelli ML, Gabelloni P, Lecca D, Rosa P, 1570 Abbracchio MP, Martini C (2011) Agonist-induced 1571 desensitization/resensitization of human $\mathrm{G}$ protein1572 coupled receptor 17: a functional cross-talk between 1573 purinergic and cysteinyl-leukotriene ligands. J 1574 Pharmacol Exp Ther 338(2):559-567

1575 Daniele S, Trincavelli ML, Fumagalli M, Zappelli E, 1576 Lecca D, Bonfanti E, Campiglia P, Abbracchio MP, 1577 Martini C (2014) Does GRK-beta arrestin machinery 1578 work as a "switch on" for GPR17-mediated activation 1579 of intracellular signaling pathways? Cell Signal 26 1580 (6):1310-1325

1581 Davalos D, Grutzendler J, Yang G, Kim JV, Zuo Y, 1582 Jung S, Littman DR, Dustin ML, Gan WB (2005) 1583 ATP mediates rapid microglial response to local 1584 brain injury in vivo. Nat Neurosci 8(6):752-758
Davenport AP, Alexander SP, Sharman JL, Pawson AJ, 1585 Benson HE, Monaghan AE, Liew WC, Mpamhanga 1586 CP, Bonner TI, Neubig RR, Pin JP, Spedding M, 1587 Harmar AJ (2013) International union of basic and 1588 clinical pharmacology. LXXXVIII G protein-coupled 1589 receptor list: recommendations for new pairings with 1590 cognate ligands. Pharmacol Rev 65(3):967-986 1591

Dougherty JD, Fomchenko EI, Akuffo AA, Schmidt E, 1592 Helmy KY, Bazzoli E, Brennan CW, Holland EC, 1593 Milosevic A (2012) Candidate pathways for promot- 1594 ing differentiation or quiescence of oligodendrocyte 1595 progenitor-like cells in glioma. Cancer Res 721596 (18):4856-4868 1597

Eberini I, Daniele S, Parravicini C, Sensi C, Trincavelli 1598 ML, Martini C, Abbracchio MP (2011) In silico iden- 1599 tification of new ligands for GPR17: a promising ther- 1600 apeutic target for neurodegenerative diseases. J 1601 Comput Aided Mol Des 25(8):743-752 1602

Eggerickx D, Denef JF, Labbe O, Hayashi Y, Refetoff S, 1603 Vassart G, Parmentier M, Libert F (1995) Molecular 1604 cloning of an orphan G-protein-coupled receptor that 1605 constitutively activates adenylate cyclase. Biochem J 1606 309(Pt 3):837-843

1607

Fancy SP, Baranzini SE, Zhao C, Yuk DI, Irvine KA, 1608 Kaing S, Sanai N, Franklin RJ, Rowitch DH (2009) 1609 Dysregulation of the Wnt pathway inhibits timely 1610 myelination and remyelination in the mammalian 1611 CNS. Genes Dev 23(13):1571-1585 1612

Ferrara G, Errede M, Girolamo F, Morando S, Ivaldi F, 1613 Panini N, Bendotti C, Perris R, Furlan R, Virgintino D, 1614 Kerlero de Rosbo N, Uccelli A (2016) NG2, a com- 1615 mon denominator for neuroinflammation, blood-brain 1616 barrier alteration, and oligodendrocyte precursor 1617 response in EAE, plays a role in dendritic cell activa- 1618 tion. Acta Neuropathol 132(1):23-42 1619

Franke H, Parravicini C, Lecca D, Zanier ER, Heine C, 1620 Bremicker K, Fumagalli M, Rosa P, Longhi L, 1621 Stocchetti N, De Simoni MG, Weber M, Abbracchio 1622 MP (2013) Changes of the GPR17 receptor, a new 1623 target for neurorepair, in neurons and glial cells in 1624 patients with traumatic brain injury. Purinergic Signal 1625 9(3):451-462 1626

Franklin RJ, Ffrench-Constant C (2008) Remyelination in 1627 the CNS: from biology to therapy. Nat Rev Neurosci 91628 (11):839-855

1629

Fratangeli A, Parmigiani E, Fumagalli M, Lecca D, 1630 Benfante R, Passafaro M, Buffo A, Abbracchio MP, 1631 Rosa P (2013) The regulated expression, intracellular 1632 trafficking and membrane recycling of the P2Y-like 1633 receptor GPR17 in Oli-neu oligodendroglial cells. J 1634 Biolog Chem 288(7):5241-5256 1635

Fredriksson R, Lagerstrom MC, Lundin LG, Schioth HB 1636 (2003) The G-protein-coupled receptors in the human 1637 genome form five main families. Phylogenetic analy- 1638 sis, paralogon groups, and fingerprints. Mol 1639 Pharmacol 63(6):1256-1272 
1641 Fumagalli M, Trincavelli L, Lecca D, Martini C, Ciana P, 1642 Abbracchio MP (2004) Cloning, pharmacological 1643 characterisation and distribution of the rat G-protein1644 coupled P2Y(13) receptor. Biochem Pharmacol 68 1645 (1):113-124

1646 Fumagalli M, Daniele S, Lecca D, Lee PR, Parravicini C, 1647 Fields RD, Rosa P, Antonucci F, Verderio C, 1648 Trincavelli ML, Bramanti P, Martini C, Abbracchio 1649 MP (2011a) Phenotypic changes, signaling pathway, 1650 and functional correlates of GPR17-expressing neural 1651 precursor cells during oligodendrocyte differentiation. 1652 J Biol Chem 286(12):10593-10604

1653 Fumagalli M, Lecca D, Abbracchio MP (2011b) Role of 1654 purinergic signalling in neuro-immune cells and adult 1655 neural progenitors. Front Biosci 16:2326-2341

1656 Fumagalli M, Bonfanti E, Daniele S, Lecca D, Martini C, 1657 Trincavelli ML, Abbracchio MP (2015) The ubiquitin 1658 ligase Mdm2 controls oligodendrocyte maturation by 1659 intertwining mTOR with $\mathrm{G}$ protein-coupled receptor 1660 kinase 2 in the regulation of GPR17 receptor desensi1661 tization. Glia in press. doi:10.1002/glia.22896

1662 Fumagalli M, Lecca D, Abbracchio MP (2016) CNS 1663 remyelination as a novel reparative approach to neu1664 rodegenerative diseases: The roles of purinergic sig1665 naling and the P2Y-like receptor GPR17. 1666 Neuropharmacology 104:82-93

1667 Garenc C, Julien P, Levy E (2010) Oxysterols in 1668 biological systems: the gastrointestinal tract, liver, 1669 vascular wall and central nervous system. Free Radic 1670 Res 44(1):47-73

1671 Hannedouche S, Zhang J, Yi T, Shen W, Nguyen D, 1672 Pereira JP, Guerini D, Baumgarten BU, Roggo S, 1673 Wen B, Knochenmuss R, Noel S, Gessier F, Kelly 1674 LM, Vanek M, Laurent S, Preuss I, Miault C, 1675 Christen I, Karuna R, Li W, Koo DI, Suply T, 1676 Schmedt C, Peters EC, Falchetto R, Katopodis A, 1677 Spanka C, Roy MO, Detheux M, Chen YA, Schultz 1678 PG, Cho CY, Seuwen K, Cyster JG, Sailer AW (2011) 1679 Oxysterols direct immune cell migration via EBI2. 1680 Nature 475(7357):524-527

1681 Haupt VJ, Daminelli S, Schroeder M (2013) Drug promis1682 cuity in PDB: protein binding site similarity is key. 1683 PLoS One 8(6):e65894

1684 Haynes SE, Hollopeter G, Yang G, Kurpius D, Dailey 1685 ME, Gan WB, Julius D (2006) The P2Y12 receptor 1686 regulates microglial activation by extracellular 1687 nucleotides. Nat Neurosci 9(12):1512-1519

1688 Hennen S, Wang H, Peters L, Merten N, Simon K, 1689 Spinrath A, Blattermann S, Akkari R, Schrage R, 1690 Schroder R, Schulz D, Vermeiren C, 1691 Zimmermann K, Kehraus S, Drewke C, Pfeifer A, 1692 Konig GM, Mohr K, Gillard M, Muller CE, Lu QR, 1693 Gomeza J, Kostenis E (2013) Decoding signaling and 1694 function of the orphan $G$ protein-coupled receptor 1695 GPR17 with a small-molecule agonist. Sci Signal 6 1696 (298):ra93

1697 Huber C, Marschallinger J, Tempfer H, Furtner T, 1698 Couillard-Despres S, Bauer HC, Rivera FJ, Aigner L 1699 (2011) Inhibition of leukotriene receptors boosts neural progenitor proliferation. Cell Physiol Biochem 1700 28(5):793-804 1701

Im DS (2004) Discovery of new G protein-coupled 1702 receptors for lipid mediators. J Lipid Res 451703 (3):410-418 1704

Im DS (2013) Intercellular lipid mediators and GPCR 1705 drug discovery. Biomol Ther 21(6):411-422 1706

Jiang Q, Guo D, Lee BX, Van Rhee AM, Kim YC, 1707 Nicholas RA, Schachter JB, Harden TK, Jacobson 1708 KA (1997) A mutational analysis of residues essential 1709 for ligand recognition at the human P2Y1 receptor. 1710 Mol Pharmacol 52(3):499-507 1711

Kanaoka Y, Maekawa A, Austen KF (2013) Identification 1712 of GPR99 protein as a potential third cysteinyl leuko- 1713 triene receptor with a preference for leukotriene E4 1714 ligand. J Biol Chem 288(16):10967-10972 1715

Kenakin T (2001) Inverse, protean, and ligand-selective 1716 agonism: matters of receptor conformation. FASEB J 1717 15(3):598-611 1718

Kotani M, Mollereau C, Detheux M, Le Poul E, 1719 Brezillon S, Vakili J, Mazarguil H, Vassart G, Zajac 1720 JM, Parmentier M (2001) Functional characterization 1721 of a human receptor for neuropeptide FF and related 1722 peptides. Br J Pharmacol 133(1):138-144 1723

Lecca D, Abbracchio MP (2008) Deorphanisation of G 1724 protein-coupled receptors: a tool to provide new 1725 insights in nervous system pathophysiology and new 1726 targets for psycho-active drugs. Neurochem Int 521727 (3):339-351 1728

Lecca D, Ceruti S (2008) Uracil nucleotides: from meta- 1729 bolic intermediates to neuroprotection and 1730 neuroinflammation. Biochem Pharmacol 751731 (10):1869-1881 1732

Lecca D, Trincavelli ML, Gelosa P, Sironi L, Ciana P, 1733 Fumagalli M, Villa G, Verderio C, Grumelli C, 1734 Guerrini U, Tremoli E, Rosa P, Cuboni S, Martini C, 1735 Buffo A, Cimino M, Abbracchio MP (2008) The 1736 recently identified P2Y-like receptor GPR17 is a sen- 1737 sor of brain damage and a new target for brain repair. 1738 PLoS One 3(10):e3579 1739

Lecca D, Marangon D, Coppolino GT, Mendez AM, 1740 Finardi A, Costa GD, Martinelli V, Furlan R, 1741 Abbracchio MP (2016) MiR-125a-3p timely inhibits 1742 oligodendroglial maturation and is pathologically 1743 up-regulated in human multiple sclerosis. Sci Rep 1744 6:34503

1745

Levit A, Beuming T, Krilov G, Sherman W, Niv MY 1746 (2014) Predicting GPCR promiscuity using binding 1747 site features. J Chem Inf Model 54(1):184-194 1748

Li M, Hale JS, Rich JN, Ransohoff RM, Lathia JD (2012) 1749 Chemokine CXCL12 in neurodegenerative diseases: 1750 an SOS signal for stem cell-based repair. Trends 1751 Neurosci 35(10):619-628 1752

Li C, Xiao L, Liu X, Yang W, Shen W, Hu C, Yang G, He 1753 C (2013) A functional role of NMDA receptor in 1754 regulating the differentiation of oligodendrocyte pre- 1755 cursor cells and remyelination. Glia 61(5):732-749 1756

Liu C, Yang XV, Wu J, Kuei C, Mani NS, Zhang L, Yu J, 1757 Sutton SW, Qin N, Banie H, Karlsson L, Sun S, 1758 
1759 Lovenberg TW (2011a) Oxysterols direct B-cell 1760 migration through EBI2. Nature 475(7357):519-523

1761 Liu C, Sage JC, Miller MR, Verhaak RG, Hippenmeyer S, 1762 Vogel H, Foreman O, Bronson RT, Nishiyama A, 1763 Luo L, Zong H (2011b) Mosaic analysis with double 1764 markers reveals tumor cell of origin in glioma. Cell 1765 146(2):209-221

1766 Maekawa A, Balestrieri B, Austen KF, Kanaoka Y (2009) 1767 GPR17 is a negative regulator of the cysteinyl leuko1768 triene 1 receptor response to leukotriene D4. Proc Natl 1769 Acad Sci U S A 106(28):11685-11690

1770 Mamedova L, Capra V, Accomazzo MR, Gao ZG, 1771 Ferrario S, Fumagalli M, Abbracchio MP, Rovati 1772 GE, Jacobson KA (2005) CysLT1 leukotriene receptor 1773 antagonists inhibit the effects of nucleotides acting at 1774 P2Y receptors. Biochem Pharmacol 71(1-2):115-125 1775 Mao FX, Li WJ, Chen HJ, Qian LH, Buzby JS (2012) 1776 Periventricular leukomalacia long-term prognosis 1777 may be improved by treatment with UDP-glucose, 1778 GDNF, and memantine in neonatal rats. Brain Res 1779 1486:112-120

1780 Marschallinger J, Schaffner I, Klein B, Gelfert R, Rivera 1781 FJ, Illes S, Grassner L, Janssen M, Rotheneichner P, 1782 Schmuckermair C, Coras R, Boccazzi M, Chishty M, 1783 Lagler FB, Renic M, Bauer HC, Singewald N, 1784 Blumcke I, Bogdahn U, Couillard-Despres S, Lie 1785 DC, Abbracchio MP, Aigner L (2015) Structural and 1786 functional rejuvenation of the aged brain by an 1787 approved anti-asthmatic drug. Nat Commun 6:8466 1788 Marteau F, Le Poul E, Communi D, Labouret C, Savi P, 1789 Boeynaems JM, Gonzalez NS (2003) Pharmacological 1790 characterization of the human P2Y13 receptor. Mol 1791 Pharmacol 64(1):104-112

1792 Marucci G, Dal Ben D, Lambertucci C, Santinelli C, 1793 Spinaci A, Thomas A, Volpini R, Buccioni M (2016) 1794 The G protein-coupled receptor GPR17: overview and 1795 update. ChemMedChem 11(23):2567-2574

1796 Mei F, Wang H, Liu S, Niu J, Wang L, He Y, 1797 Etxeberria A, Chan JR, Xiao L (2013) Stage-specific 1798 deletion of Olig2 conveys opposing functions on dif1799 ferentiation and maturation of oligodendrocytes. J 1800 Neurosci 33(19):8454-8462

1801 Meraviglia V, Ulivi AF, Boccazzi M, Valenza F, 1802 Fratangeli A, Passafaro M, Lecca D, Stagni F, 1803 Giacomini A, Bartesaghi R, Abbracchio MP, 1804 Ceruti S, Rosa P (2016) SNX27, a protein involved 1805 in down syndrome, regulates GPR17 trafficking and 1806 oligodendrocyte differentiation. Glia 64 1807 (8): $1437-1460$

1808 Mitew S, Hay CM, Peckham H, Xiao J, Koenning M, 1809 Emery B (2013) Mechanisms regulating the develop1810 ment of oligodendrocytes and central nervous system 1811 myelin. Neuroscience 276:29-47

1812 Nakatani H, Martin E, Hassani H, Clavairoly A, Maire 1813 CL, Viadieu A, Kerninon C, Delmasure A, Frah M, 1814 Weber M, Nakafuku M, Zalc B, Thomas JL, 1815 Guillemot F, Nait-Oumesmar B, Parras C (2013) 1816 Ascl1/Mash1 promotes brain oligodendrogenesis during myelination and remyelination. J Neurosci 331817 (23):9752-9768 1818

Ou Z, Sun Y, Lin L, You N, Liu X, Li H, Ma Y, Cao L, 1819 Han Y, Liu M, Deng Y, Yao L, Lu QR, Chen Y (2016) 1820 Olig2-targeted G-protein-coupled receptor Gpr17 1821 regulates oligodendrocyte survival in response to 1822 lysolecithin-induced demyelination. J Neurosci 361823 (41):10560-10573 1824

Parravicini C, Ranghino G, Abbracchio MP, Fantucci P 1825 (2008) GPR17: molecular modeling and dynamics 1826 studies of the 3-D structure and purinergic ligand 1827 binding features in comparison with $\mathrm{P} 2 \mathrm{Y}$ receptors. 1828 BMC Bioinf 9:263

1829

Parravicini C, Abbracchio MP, Fantucci P, Ranghino G 1830 (2010) Forced unbinding of GPR17 ligands from wild 1831 type and R255I mutant receptor models through a 1832 computational approach. BMC Struct Biol 10:8 1833

Parravicini C, Daniele S, Palazzolo L, Trincavelli ML, 1834 Martini C, Zaratin P, Primi R, Coppolino G, 1835 Gianazza E, Abbracchio MP, Eberini I (2016) A pro- 1836 miscuous recognition mechanism between GPR17 and 1837 SDF-1: molecular insights. Cell Signal 28(6):631-642 1838

Paruchuri S, Tashimo H, Feng C, Maekawa A, Xing W, 1839 Jiang Y, Kanaoka Y, Conley P, Boyce JA (2009) 1840 Leukotriene E4-induced pulmonary inflammation is 1841 mediated by the P2Y12 receptor. J Exp Med 2061842 (11):2543-2555

1843

Patel JR, McCandless EE, Dorsey D, Klein RS (2010) 1844 CXCR4 promotes differentiation of oligodendrocyte 1845 progenitors and remyelination. Proc Natl Acad Sci U S 1846 A 107(24):11062-11067

1847

Pugliese AM, Trincavelli ML, Lecca D, Coppi E, 1848 Fumagalli M, Ferrario S, Failli P, Daniele S, 1849 Martini C, Pedata F, Abbracchio MP (2009) Func- 1850 tional characterization of two isoforms of the 1851 P2Y-like receptor GPR17: [35S]GTPgammaS binding 1852 and electrophysiological studies in 1321N1 cells. Am 1853 J Physiol Cell Physiol 297(4):C1028-C1040 1854

Qi AD, Harden TK, Nicholas RA (2013) Is GPR17 a 1855 $\mathrm{P} 2 \mathrm{Y} /$ leukotriene receptor? examination of uracil 1856 nucleotides, nucleotide sugars, and cysteinyl 1857 leukotrienes as agonists of GPR17. J Pharmacol Exp 1858 Ther 347(1):38-46 1859

Qin Y, Verdegaal EM, Siderius M, Bebelman JP, Smit 1860 MJ, Leurs R, Willemze R, Tensen CP, Osanto S 1861 (2011) Quantitative expression profiling of G-protein- 1862 coupled receptors (GPCRs) in metastatic melanoma: 1863 the constitutively active orphan GPCR GPR18 as 1864 novel drug target. Pigment Cell Melanoma Res 241865 (1):207-218

1866

Raccosta L, Fontana R, Maggioni D, Lanterna C, 1867 Villablanca EJ, Paniccia A, Musumeci A, 1868 Chiricozzi E, Trincavelli ML, Daniele S, Martini C, 1869 Gustafsson JA, Doglioni C, Feo SG, Leiva A, Ciampa 1870 MG, Mauri L, Sensi C, Prinetti A, Eberini I, Mora JR, 1871 Bordignon C, Steffensen KR, Sonnino S, Sozzani S, 1872 Traversari C, Russo V (2013) The oxysterol-CXCR2 1873 
1874 axis plays a key role in the recruitment of tumor1875 promoting neutrophils. J Exp Med 210(9):1711-1728 1876 Rajagopalan L, Rajarathnam K (2004) Ligand selectivity 1877 and affinity of chemokine receptor CXCR1. Role of 1878 N-terminal domain. J Biol Chem 279 1879 (29):30000-30008

1880 Rosenkilde MM, Benned-Jensen T, Andersen H, Holst PJ, 1881 Kledal TN, Luttichau HR, Larsen JK, Christensen JP, 1882 Schwartz TW (2006) Molecular pharmacological 1883 phenotyping of EBI2. An orphan seven1884 transmembrane receptor with constitutive activity. J 1885 Biol Chem 281(19):13199-13208

1886 Salituro FG, Harrison BL, Baron BM, Nyce PL, Stewart 1887 KT, Kehne JH, White HS, McDonald IA (1992) 1888 3-(2-Carboxyindol-3-yl)propionic acid-based 1889 antagonists of the N-methyl-D-aspartic acid receptor 1890 associated glycine binding site. J Med Chem 35 1891 (10):1791-1799

1892 Sensi C, Daniele S, Parravicini C, Zappelli E, Russo V, 1893 Trincavelli ML, Martini C, Abbracchio MP, Eberini I 1894 (2014) Oxysterols act as promiscuous ligands of class1895 A GPCRs: in silico molecular modeling and in vitro 1896 validation. Cell Signal 26(12):2614-2620

1897 Temporini C, Ceruti S, Calleri E, Ferrario S, Moaddel R, 1898 Abbracchio MP, Massolini G (2009) Development of 1899 an immobilized GPR17 receptor stationary phase for 1900 binding determination using frontal affinity chroma1901 tography coupled to mass spectrometry. Anal 1902 Biochem 384(1):123-129

1903 Tyler WA, Jain MR, Cifelli SE, Li Q, Ku L, Feng Y, Li H, 1904 Wood TL (2011) Proteomic identification of novel 1905 targets regulated by the mammalian target of 1906 rapamycin pathway during oligodendrocyte differen1907 tiation. Glia 59(11):1754-1769

1908 Uhlenbrock K, Gassenhuber H, Kostenis E (2002) Sphin1909 gosine 1-phosphate is a ligand of the human gpr3, gpr6 1910 and gpr12 family of constitutively active $G$ protein1911 coupled receptors. Cell Signal 14(11):941-953

1912 Vigano F, Schneider S, Cimino M, Bonfanti E, Gelosa P, 1913 Sironi L, Abbracchio MP, Dimou L (2016) GPR17 1914 expressing NG2-Glia: oligodendrocyte progenitors 1915 serving as a reserve pool after injury. Glia 64 1916 (2):287-299

1917 Wang L, Du C, Lv J, Wei W, Cui Y, Xie X (2011) 1918 Antiasthmatic drugs targeting the cysteinyl leukotri1919 ene receptor 1 alleviate central nervous system inflam1920 matory cell infiltration and pathogenesis of 1921 experimental autoimmune encephalomyelitis. J 1922 Immunol 187(5):2336-2345

1923 Wheatley M, Wootten D, Conner MT, Simms J, 1924 Kendrick R, Logan RT, Poyner DR, Barwell J (2012)
Lifting the lid on GPCRs: the role of extracellular 1925 loops. Br J Pharmacol 165(6):1688-1703 1926

Whitney LW, Ludwin SK, McFarland HF, Biddison WE 1927 (2001) Microarray analysis of gene expression in mul- 1928 tiple sclerosis and EAE identifies 5-lipoxygenase as a 1929 component of inflammatory lesions. J Neuroimmunol 1930 121(1-2):40-48

Wu B, Chien EY, Mol CD, Fenalti G, Liu W, Katritch V, 1932 Abagyan R, Brooun A, Wells P, Bi FC, Hamel DJ, 1933 Kuhn P, Handel TM, Cherezov V, Stevens RC (2010) 1934 Structures of the CXCR4 chemokine GPCR with 1935 small-molecule and cyclic peptide antagonists. Sci- 1936 ence 330(6007):1066-1071 1937

Ye F, Chen Y, Hoang T, Montgomery RL, Zhao XH, 1938 Bu H, Hu T, Taketo MM, van Es JH, Clevers H, 1939 Hsieh J, Bassel-Duby R, Olson EN, Lu QR (2009) 1940 HDAC1 and HDAC2 regulate oligodendrocyte differ- 1941 entiation by disrupting the beta-catenin-TCF interac- 1942 tion. Nat Neurosci 12(7):829-838 1943

Yu GL, Wei EQ, Wang ML, Zhang WP, Zhang SH, Weng 1944 JQ, Chu LS, Fang SH, Zhou Y, Chen Z, Zhang Q, 1945 Zhang LH (2005a) Pranlukast, a cysteinyl leukotriene 1946 receptor-1 antagonist, protects against chronic ische- 1947 mic brain injury and inhibits the glial scar formation in 1948 mice. Brain Res 1053(1-2):116-125 1949

Yu GL, Wei EQ, Zhang SH, Xu HM, Chu LS, Zhang WP, 1950 Zhang Q, Chen Z, Mei RH, Zhao MH (2005b) 1951 Montelukast, a cysteinyl leukotriene receptor-1 antag- 1952 onist, dose- and time-dependently protects against 1953 focal cerebral ischemia in mice. Pharmacology 731954 (1):31-40 1955

Zhang K, Zhang J, Gao ZG, Zhang D, Zhu L, Han GW, 1956 Moss SM, Paoletta S, Kiselev E, Lu W, Fenalti G, 1957 Zhang W, Muller CE, Yang H, Jiang H, Cherezov V, 1958 Katritch V, Jacobson KA, Stevens RC, Wu B, Zhao Q 1959 (2014) Structure of the human P2Y12 receptor in 1960 complex with an antithrombotic drug. Nature 5091961 (7498):115-118

1962

Zhang D, Gao ZG, Zhang K, Kiselev E, Crane S, Wang J, 1963 Paoletta S, Yi C, Ma L, Zhang W, Han GW, Liu H, 1964 Cherezov V, Katritch V, Jiang H, Stevens RC, 1965 Jacobson KA, Zhao Q, Wu B (2015) Two disparate 1966 ligand-binding sites in the human P2Y1 receptor. 1967 Nature 520(7547):317-321 1968

Zhao B, Zhao CZ, Zhang XY, Huang XQ, Shi WZ, Fang 1969 SH, Lu YB, Zhang WP, Xia Q, Wei EQ (2012) The 1970 new P2Y-like receptor $G$ protein-coupled receptor 1971 17 mediates acute neuronal injury and late 1972 microgliosis after focal cerebral ischemia in rats. Neu- 1973 roscience 202:42-57 


\section{Author Queries}

Chapter No.: 92

\begin{tabular}{|l|l|l|}
\hline Query Refs. & Details Required & Author's response \\
\hline AU1 & $\begin{array}{l}\text { Strikeout text has been deleted in the caption of } \\
\text { Fig. 3. Please confirm if it is oaky. }\end{array}$ & \\
\hline AU2 & $\begin{array}{l}\text { Strike-out text has been deleted in the text. } \\
\text { Please check and confirm if this okay. }\end{array}$ & \\
\hline
\end{tabular}

